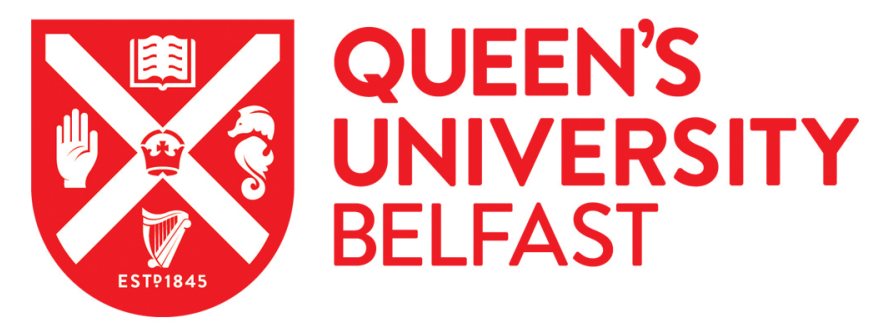

\title{
Transfer processes of potentially toxic metals (PTMs) between rock- soil systems and soil risk evaluation in the Baoshan area, Yunnan province, Southwest China
}

Zhang, L., McKinley, J., Cooper, M., Han, W., Lui, F., Song, Y., Peng, M., Liu, X., Yang, W., \& Cheng, H. (2020). Transfer processes of potentially toxic metals (PTMs) between rock-soil systems and soil risk evaluation in the Baoshan area, Yunnan province, Southwest China. Applied Geochemistry.

https://doi.org/10.1016/j.apgeochem.2020.104712

Published in:

Applied Geochemistry

Document Version:

Peer reviewed version

Queen's University Belfast - Research Portal:

Link to publication record in Queen's University Belfast Research Portal

\section{General rights}

Copyright for the publications made accessible via the Queen's University Belfast Research Portal is retained by the author(s) and / or other copyright owners and it is a condition of accessing these publications that users recognise and abide by the legal requirements associated with these rights.

\section{Take down policy}

The Research Portal is Queen's institutional repository that provides access to Queen's research output. Every effort has been made to ensure that content in the Research Portal does not infringe any person's rights, or applicable UK laws. If you discover content in the Research Portal that you believe breaches copyright or violates any law, please contact openaccess@qub.ac.uk. 


\section{Transfer processes of potentially toxic metals}

2 (PTMs) between rock-soil systems and soil risk

3 evaluation in the Baoshan area, Yunnan province,

5 Li Zhang ${ }^{a, b, c, d}$, Jennifer McKinley ${ }^{d}$, Mark Cooper ${ }^{e}$, Min Peng ${ }^{a, b, c}$, Wei Han, ${ }^{a, c}$ Yuntao Song

6 a,c, Fei Liu ${ }^{a, c}$ Xiujin Liu ${ }^{a, c}$, Hangxin Cheng ${ }^{a, c *}$

7 a. Key Laboratory of Geochemical Cycling of Carbon and Mercury in the Earth's

8 Critical Zone, Institute of Geophysical \& Geochemical Exploration, Chinese Academy

9 of Geological Sciences, Langfang 065000, China

b. China University of Geosciences, Beijing 100083, China

c. Research Center of Geochemical Survey and Assessment on Land Quality, China

d. School of Natural and Built Environment, Queen's University Belfast, Belfast BT7

$14 \quad 1 \mathrm{NN}, \quad \mathrm{UK}$

e. Geological Survey of Northern Ireland, Belfast, BT4 3SB, UK

*corresponding author at: Key Laboratory of Geochemical Cycling of Carbon and

Cheng)

Highlights:

* Geochemical flux of rock-soil from different geological formations were revealed 
* The geochemical flux indicates a lithological origin for PTMs

* Igeo and EF may underestimate PTMs contamination in high geological background areas

* Geochemical background values should be proper chose when calculate

* Mining activities contributions to soil contaminations of PTMs near the mining areas

\section{Abstract}

Geochemical fluxes in rock-soil systems are an important tool to evaluate soil environmental risk, especially where the geological background (parent materials) are enriched in potentially toxic metals (PTMs). In the Baoshan area, the presence of mineral resources and carbonate and basalt parent materials often leads to PTMs being elevated in soils. In this study, we compared rock and soil geochemical compositions by collecting rock samples from the host formations and ore samples from two mineral deposits $(\mathrm{Cu}-\mathrm{Pb}-\mathrm{Zn}$ and $\mathrm{Fe}-\mathrm{Cu}-\mathrm{Pb}-\mathrm{Zn})$ and their overlying soils. This research demonstrates enrichment of PTMs (As, $\mathrm{Cd}, \mathrm{Cr}, \mathrm{Cu}, \mathrm{Hg}, \mathrm{Ni}, \mathrm{Pb}$ and $\mathrm{Zn}$ ) in soils relative to their parent materials. The enrichment in soils may be due to the removal of mobile elements (e.g., $\mathrm{Ca}$, Na, $\mathrm{Mg}$, and $\mathrm{Sr}$ ), and coprecipitation (As, $\mathrm{Cd}, \mathrm{Cr}, \mathrm{Cu}$, $\mathrm{Hg}, \mathrm{Ni}, \mathrm{Pb}$ and $\mathrm{Zn}$ ) and/or adsorption by $\mathrm{Fe}^{-} \mathrm{oxy}$-hydroxides ( $\mathrm{Cr}$ and $\mathrm{Ni}$ ) under the influence of high $\mathrm{pH}$ values during soils formation. The results point to a parent lithological origin and natural enrichment of PTMs in Baoshan soils. However, anthropogenic contamination of soils near mining areas is also possible. Soils forming from carbonate rocks, basalts, and especially from mineralized formations 
have higher PTMs concentrations, and in places, levels can exceed the risk screening values for soil contamination of agricultural land of China. Where the latter is the case, it is suggested that ecological monitoring be implemented in the study area. The geo-accumulation index $\left(\mathrm{I}_{\text {geo }}\right)$ and enrichment factor $(\mathrm{EF})$ methods used may underestimate the PTMs contamination, and comparison with larger-scale background datasets when calculating results may be a better way to evaluate soil environment risk in high geological background areas.

Keywords: Potentially toxic metals (PTMs); Rock-soil systems; Geochemical fluxes; Geo-accumulation index ( $\left.\mathrm{I}_{\text {geo }}\right)$; Enrichment factor (EF); Southwest China

\section{Introduction}

\section{Soil sustains all terrestrial organisms and is the medium for all biogeochemical} processes. However, it is a finite resource that is not renewable on a human time scale (Purswani and Pathak, 2018). With competing pressures between population, resources and environment, soil quality has become a major concern globally (Antibachi et al., 2012; Cheng et al., 2014a; Cheng et al., 2014b; Cheng et al., 2014d; Cicchella et al., 2008; Gong et al., 2014; Li et al., 2010; Li et al., 2014b; Luo et al., 2012; Zhang et al., 2013). Source of potentially toxic metals (PTMs) are most often considered to be anthropogenic in origin (e.g. industrial and mining activities, agricultural fertilization, and irrigation and urban living pollutants).

Such sources have been recognized by public authorities and well researched by scientists. (Addo et a1., 2012; Akopyan et al. ; Cabral Pinto et al., 2018; 2019a; 
2019b; Chiu et al., 2016; Ettler, 2016; Hamzeh et al., 2011; Li et al., 2014b; Luo et al., 2012; McGrath and Tunney, 2010; Pinto et al., 2004; Poňavič et al., 2018; Rate, 2018). Soil can be naturally contaminated due to release of PTMs from parent materials during weathering and this is evidenced by a significant body of research in this field e.g. (Antibachi et al., 2012; Becquer et al., 2006; Bompoti et al., 2015; Bonifacio et al., 2010; Kelepertzis et al., 2013; Tashakor et al., 2014). Therefore, it is crucial to understand geochemical fluxes rock-soil systems, especially where the geological background (parent materials) are enriched in PTMs. Understanding these fluxes will provide an important tool for assessing the natural environmental/ecological risk to soils. In this study, we examine geochemical fluxes at a regional scale. This has been achieved through the collection of rock samples from the host rock sequences, ore samples from two mineral deposits (HTTP: $\mathrm{Cu}-\mathrm{Pb}-\mathrm{Zn}$ and HYA: $\mathrm{Fe}-\mathrm{Cu}-\mathrm{Pb}-\mathrm{Zn}$ ), and samples from overlying soils. In this and other areas, the presence of carbonate and basalt parent materials often leads to elevated PTMs in soil (Barsby et al., 2012; Cabral Pinto et al., 2017; Cheng, 2016; Cox et al., 2017; Goldhaber et al., 2009; Tolosana-Delgado and McKinley, 2016; Wang et al., 2015; Zhang et a1., 2002).

Statistical analysis of geochemical data from different geological formations and their overlying soils was used to (1) reveal the concentration of PTMs in the rock-soil systems in the study area, (2) evaluate the enrichment and depletion of PTMs in soils related to their underlying rock formations, (3) understand the transfer processes of PTMs from rocks to soils, and (4) evaluate ecological risk 


\section{Research area}

The Baoshan area is located in southwest China in the Yunnan province (Fig. 1a). The area has a mild subtropical that is tempered by its low latitude and moderate elevation. Baoshan has short, mild, dry winters, and warm, rainy summers. Contour maps of altitude, average surface soil temperature and rainfall are shown in Fig. 2. Variations in average temperature are directly related to altitude, whilst rainfall is greatest in the western and southern parts of the study area. The main types of land-use in the study area are forested land, dry cultivated land, paddy land, grassland, garden plot, with few water areas and other types (residential quarter and industrial and mining land, and unused land) (Fig. 3a). The main soil types in the study area are red soils, yellow red soils, yellow crimson red soils, dry red soils, yellow brown soils, dark yellow brown soils, paddy soils with few brown soils, acid purple soils and other types (Fig. 3b).

Geologically, the area is located in the Sanjiang area of the Yunnan province, which consists of the Tengchong, Baoshan, and Lanping-Simao blocks (Fig. 1b) (Dong et a1., 2013; Li et a1., 2015; Wang et al., 2010). Rocks of the Baoshan Block are mainly Paleozoic to Mesozoic sedimentary rocks, and early Paleozoic and late Mesozoic-early Cenozoic magmatic rocks (Dong et al., 2013; Wang et a1., 2013). From the Precambrian to Quaternary, the main rock type for each era is shown in Fig. 4. Basalt occurs in the Carboniferous and Jurassic rock sequences that are mainly 
distributed in the western and northeast parts of the study area. Whilst mineral deposits, which are often associated with PTMs pollution in soil, are widely distributed across the study area (copper, lead, zinc, mercury, gold, titanium and coal, etc., ) (Fig. 4).

\section{Methodology}

\subsection{Sampling methods}

An area of $6220 \mathrm{~km}^{2}$ of the 2016 National Geochemistry Survey of Land Quality project (NGSLQ) was selected as the research area because of the range of bedrock geology and mineralization present. Samples of bedrock from all the main rock groupings and their overlying soils were collected. Additionally, ore samples from two deposits (the Hetaoping copper-lead-zinc deposit (HTP) and Heiyanao iron-copper-lead-zinc deposit (HYA)) and their overlying soils were also taken. The sampling locations did not follow a predetermined criterion, as their selection required finding bedrock outcrops with or without mineralization and overlying soil. In total 102 rock samples from 9 geological formations, including 20 rock samples from the two basalt formations (Carboniferous and Jurassic), and 20 mineralized samples were collected. The sample details are provided in Table 1. Corresponding surface soil for each rock/ore sample, at 0-20 cm depth, were collected. Soil samples were composited from 3 to 5 subsamples collected within 50 m of each bedrock sample site. Soil samples were $\geqslant 1 \mathrm{Kg}$, and visible plant detritus and rock fragments were removed during collection. The detailed soil type, soil 
characteristic, parent rocks/formations, and sample numbers are showed in Table 2.

All the sampling positions were pinpointed by the Global Positioning System (GPS).

The sample locations are shown in Fig. 5 .

Obvious mineral veins material was removed from the rock samples. Ore samples and the remainder of rocks were grounded using an agate mortar to -200 mesh $(<0.074$ mm) for analysis. The soil samples were disaggregated using a wooden hammer during air-drying and sieved with -20 mesh screen $(<0.84 \mathrm{~mm})$, once dried they were further processed to -200 mesh $(<0.074 \mathrm{~mm})$ for total content analysis and -100 mesh $(<$ $0.25 \mathrm{~mm}$ ) for extractable $\mathrm{As}, \mathrm{Cd}, \mathrm{Pb}$ analysis.

\subsection{Chemical analysis and quality control}

Rock/ore and soil samples were analyzed for total content by XRF $\left(\mathrm{Al}_{2} \mathrm{O}_{3}, \mathrm{TFe}_{2} \mathrm{O}_{3}\right.$, $\left.\mathrm{K}_{2} \mathrm{O}, \mathrm{SiO}_{2}, \mathrm{Na}_{2} \mathrm{O}, \mathrm{MgO}, \mathrm{CaO}\right)$ after digestion by lithium tetraborate $\left(\mathrm{Li}_{2} \mathrm{~B}_{4} \mathrm{O}_{7}\right)$; by XRF (Zr and Hf) after powder pressing; by ICP-OES (Ba, Ni, Sr, Cr, ) and ICP-MS (Cd, Cu, Cs, $\mathrm{Pb}, \mathrm{Rb}, \mathrm{Ta}, \mathrm{Th}, \mathrm{U}, \mathrm{Zn}$ and $\mathrm{Nb}$ ), after digestion by hydrofluoric acid (HF), hydrochloric acid $(\mathrm{HCl})$, nitric acid $\left(\mathrm{HNO}_{3}\right)$ and perchloric acid $\left(\mathrm{HClO}_{4}\right)$; by AFS (As, $\mathrm{Hg}$ ) after digestion with aqua regia; by HFIR (S), add tungsten grain in high-frequency infrared carbon sulfur meter; by VOL (C. org) after digestion by potassium dichromate $\left(\mathrm{K}_{2} \mathrm{Cr}_{2} \mathrm{O}_{7}\right)$ and concentrated sulfuric acid $\left(\mathrm{H}_{2} \mathrm{SO}_{4}\right)$; and by ISE $(\mathrm{pH})$ after dissolved in $\mathrm{CO}_{2}$ distilled water. Extractable $\mathrm{As}, \mathrm{Cd}, \mathrm{Pb}$ from soil samples were digested using calcium chloride $\left(\mathrm{CaCl}_{2}\right)$ and analyzed by AFS (As) and ICP-MS $(\mathrm{Cd}$ and $\mathrm{Pb})$. The analysis finished at the Geological Experimental Testing Center, 
150

151

152

Hubei province, China, which is one of the geological laboratories by accredited by the NGSLQ project. The analytical methods brand and the model of analysis devices, and detection limits were listed in Table 3. Internal and external controls were implemented during routine analysis to check accuracy and precision. Briefly, certified reference materials (CRMs) and blind reference materials (BRMs) were analyzed with samples simultaneously to control the quality of sample analysis. The detailed description can be seen in (Li et al., 2014a). The accuracies and precisions of all elements in all samples satisfy the analytical requirements developed in the NGSLQ project (CGS, 2005, 2014) and Code of Geochemical Rock Survey of China (Ministry of Land and Resources of the People's Republic of China, 2014).

\subsection{Statistical analysis}

Geochemical data are compositional data, in which the concentrations of each element are not changed independently and freely, but must accommodate to each other within the constant sum constraint of the closed composition. Which was identified to induce spurious behavior on the correlation coefficient (Chayes, 1960). Aitchison and his fellower researchers have developed the compositional data analysis methods to make the classical (Euclidean) statistical methods applied to compositional data available (Aitchison 1981, 1982, 1986; Egozcue et al. 2003; Boogaart and Tolosana-Delgado, 2013; Egozcue et a1., 2003; Pawlowsky-Glahn and Buccianti, 2011; Pawlowsky-Glahn and Egozcue, 2001).

In this paper, centred log-ratio transformation (clr) are used in CoDAPack to 
171

“open” the raw data, before statistical analysis. CoDAPack is a freeware package that implements most of the basic statistical methods suitable for compositional data (Thio-Henestrosa and Martin-Fernandez, 2006). Origin 2020 software was used for principal component analysis (PCA) on the log-ratio (clr) transformed data, using a correlation matrix, to determine the associations of chemical elements.

\title{
4. Results and discussion
}

\subsection{Chemical characteristics of rocks and soils}

\author{
4. 1.1 Rocks
}

Within the study area, the formations are distinguished based on the main rock type and these differ for most of the formations. Average (median value) concentrations of chemical elements of rocks from different geological formations and ores of the Baoshan area are shown in Table 4. Formations with carbonate rocks as their main rock type $(€-3, \mathrm{D}, \mathrm{C}, \mathrm{T}-1, \mathrm{~T}-2, \mathrm{~J})$, those with mudstone and sandstone as main rock types $(\epsilon-1, \epsilon-2,0, S)$, and those with basalts in Carboniferous and Jurassic stratum (Ba-1 and $\mathrm{Ba}-2)$ and ores from mineral deposits all display different chemical characteristics.

The carbonate formations have higher median values of $\mathrm{CaO}$ and $\mathrm{Sr}$ and lower $\mathrm{Al}_{2} \mathrm{O}_{3}$, $\mathrm{Fe}_{2} \mathrm{O}_{3}, \mathrm{MgO}, \mathrm{SiO}_{2}, \mathrm{Ba}, \mathrm{Cr}, \mathrm{Cs}, \mathrm{Cu}, \mathrm{Hf}, \mathrm{Nb}, \mathrm{Ni}, \mathrm{Pb}, \mathrm{Rb}, \mathrm{Ta}, \mathrm{Th}, \mathrm{U}, \mathrm{Zn}$ and $\mathrm{Zr}$ compare to other formations apart from dolomite (T-2) which has the highest Mg0 content. 
191

Sr and lower $\mathrm{Cs}, \mathrm{Rb}, \mathrm{Th}, \mathrm{U}$ contents compared to other formations. Mudstone and sandstone formations have higher median value of $\mathrm{K}_{2} \mathrm{O}, \mathrm{SiO}_{2}, \mathrm{Ba}, \mathrm{Cs}, \mathrm{Nb}, \mathrm{Rb}, \mathrm{Ta}, \mathrm{Th}$, $\mathrm{U}$ and $\mathrm{Zr}$ and lower $\mathrm{CaO}$ and Sr. Ore samples from the HTP and HYA mining areas have the highest median values of $\mathrm{Fe}_{2} \mathrm{O}_{3}, \mathrm{As}, \mathrm{Hg}, \mathrm{Cd}, \mathrm{Cu}, \mathrm{Pb}, \mathrm{Zn}$, and $\mathrm{S}$.

To identify geochemical associations between the elements analyzed in the rocks and ores, PCA was performed using the centred log-ratio transformed (clr) data. The numerical output with the eigenvalues $\geqslant 1$ (PC1: $46.9 \%$ of variance, PC2: 19. 1\% of variance, PC3: $11.7 \%$ of variance, and PC4: $4.5 \%$ of variance) of principal components are listed in (Table 5), which captured potentially useful information. But only the first 3 principal components are examined here. The biplots of the principal components for the clr-transformed data of rocks and ores are shown in Fig. 6. With the aid of Table 5 and Fig. 6, the following observations have been made:

$\mathrm{PC1}$ has the greatest positive contributions from $\mathrm{As}, \mathrm{Cd}, \mathrm{Hg}, \mathrm{Pb}, \mathrm{Zn}$ and $\mathrm{S}$; and the strongest negative contributions from $\mathrm{Al}_{2} \mathrm{O}_{3}, \mathrm{Cr}$, $\mathrm{Hf}, \mathrm{Nb}, \mathrm{Rb}, \mathrm{Ta}$, Th, and $\mathrm{Zr}$. PC2 had great positive contributions from $\mathrm{CaO}, \mathrm{MgO}$ and $\mathrm{Sr}$; and strong negative contributions from $\mathrm{TFe}_{2} \mathrm{O}_{3}, \mathrm{Cu}$ and $\mathrm{SiO}_{2}$. PC3 had great positive contributions from $\mathrm{Cs}, \mathrm{Rb}, \mathrm{Th}$ and $\mathrm{U}$; and strong negative contribution from $\mathrm{Na}_{2} \mathrm{O}$.

Several approximate elemental associations can be seen from component loadings in PC1-PC2, and PC1-PC3 space: chalcophile element ( $\mathrm{Cu}, \mathrm{As}, \mathrm{Cd}, \mathrm{Hg}, \mathrm{Pb}, \mathrm{Zn}$ and S) occupied the $+\mathrm{PC} 1 / \pm \mathrm{PC} 2$ quadrant (Fig. 6a). This group of elements is related to ore samples from HTP and HYA. It clearly shows the influence of mineralization and its typical ore minerals, such as galena $(\mathrm{Pb}, \mathrm{S})$, chalcopyrite ( $\mathrm{Cu}, \mathrm{Fe}, \mathrm{S})$, 
sphalerite (Zn, S), pyrite (Fe, S), chalcopyrite ( $\mathrm{Cu}, \mathrm{Fe}, \mathrm{S})$ pyrrhotite (Fe, S), magnetite $(\mathrm{Fe})$, hematite $(\mathrm{Fe}, 0)$. Arsenic and $\mathrm{Hg}$ are accessory elements that accompany $\mathrm{Cu}-\mathrm{Pb}-\mathrm{Zn}$ mineralization. Cd normally replacement of $\mathrm{Zn}$ due to their enriched in lithophile elements in lithologies. CaO, Sr, and Mg0 were grouped in the +PC1/+PC2 quadrant (Fig. 6a). Those elements are related to the carbonate compare to other rocks. The siderophile elements (Fe, $\mathrm{Cr}$, Ni and Mg0) occupied the chromite, titanite, opaque minerals and serpentine) (Cabral Pinto et al., 2017).

\section{1. 2 Soils} area are showed in Table 6. 
basalt formations ( $\mathrm{Ba}-1$ and $\mathrm{Ba}-2)$, have higher $\mathrm{Ca} 0$, Sr contents and $\mathrm{pH}$ value than seen for others. Conversely, soils overlying mudstone and sandstone formations $(\epsilon-1$, $\epsilon-2, \quad 0, \mathrm{~S})$ have lower $\mathrm{Ca} 0, \mathrm{Sr}$ and $\mathrm{pH}$ compared to soil overlying other formations. The soils overlying basalt formations (Ba-1 and $\mathrm{Ba}-2$ ) have higher $\mathrm{TFe}_{2} \mathrm{O}_{3}, \mathrm{Na}_{2} \mathrm{O}, \mathrm{Mg} 0$, $\mathrm{SiO}_{2}, \mathrm{Cr}$ and Ni. Soils overlying carbonate formations also show enrichment of $\mathrm{Cr}$ and Ni. The soils overlying $\epsilon^{-1}$ and $\epsilon^{-2}$ and near the HTP and HYA mining areas have higher organic carbon (C. org) than other soils, whilst no obvious difference of C. org was found among soils overlying other formations.

The numerical output with the eigenvalues $\geqslant 1$ (PC1: 33. 3\% of variance, PC2: 27. 2\% of variance, $\mathrm{PC} 3: 9.0 \%$ of variance, and PC4: $8.0 \%$ of variance, PC5: $6.27 \%$ of variance, PC6: $3.87 \%$ of variance) from the principal component of soil are listed in Table 7. But only the first 3 principal components are examined here. With the aid of Table 7 and Fig. 7, the following observations were made:

$\mathrm{PC} 1$ has the greatest positive contributions from $\mathrm{As}, \mathrm{Cd}, \mathrm{Cu}, \mathrm{Pb}$ and $\mathrm{Zn}$; and the strongest negative contributions from $\mathrm{Al}_{2} \mathrm{O}_{3}, \mathrm{SiO}_{2}, \mathrm{Hf}, \mathrm{Nb}, \mathrm{Ta}, \mathrm{Th}, \mathrm{U}$ and $\mathrm{Zr}$. PC2 had great positive contributions from $\mathrm{K}_{2} \mathrm{O}, \mathrm{Rb}, \mathrm{Th}$ and $\mathrm{U}$; and strong negative contributions from $\mathrm{Ca} 0, \mathrm{TFe}_{2} \mathrm{O}_{3}, \mathrm{Na}_{2} \mathrm{O}, \mathrm{Mg} 0, \mathrm{Cr}, \mathrm{Ni}, \mathrm{Sr}$ and $\mathrm{pH} . \mathrm{PC} 3$ had great negative contributions from Ba, S and C. org.

Several associations were apparent from component loadings plotted in PC1-PC2, and PC2-PC3 space: chalcophile element ( $\mathrm{Cu}, \mathrm{As}, \mathrm{Cd}, \mathrm{Hg}, \mathrm{Pb}, \mathrm{Zn}$ and S) occupied the $+\mathrm{PC1} / \pm \mathrm{PC} 2$ quadrant (Fig. 7a). This group of elements is related to soil samples from near the HTP and HYA deposits and inherits the geochemical characteristics of 

and $\mathrm{Rb}$ occupied the $-\mathrm{PC} 1 / \pm \mathrm{PC} 2$ quadrant (Fig. 7a). It clearly shows the influence of sandstone and mudstone which are enriched in those lithophile elements and soils from carbonate formations $(\epsilon-3, \mathrm{D}, \mathrm{C}, \mathrm{T}-1)$ due to the coprecipitation of insoluble elements during wreathing and soil formation processes. Siderophile element (Fe, $\mathrm{Cr}$ and $\mathrm{Ni}$ and $\mathrm{CaO}$ and $\mathrm{MgO}$ ) and $\mathrm{pH}$ occupied the $\pm \mathrm{PC1}$ / - PC2 quadrant (Fig. 7a), which in one way are related to basalts, which are enriched in Fe, Cr, Ni, Mg, Ca compare to other rock types. The soils forming from basalts inherit the geochemistry characteristic of their parent material. The other way is due to the removal of mobile elements (e.g., $\mathrm{Ca}, \mathrm{Na}, \mathrm{Mg}$ and $\mathrm{Sr}$ ) and the insoluble element (e.g., $\mathrm{Cr}$ and $\mathrm{Ni}$ ) coprecipitation and/or adsorption by $\mathrm{Fe}^{-} \mathrm{Oxy}$-hydroxides under the influence of high $\mathrm{pH}$ values. The soils overlying carbonate formations $\mathrm{J}$ and $\mathrm{T}-2$ are enriched in $\mathrm{Cr}$ and Ni due to that reason. Potentially toxic metals (PTMs) coprecipitation and/or adsorption by $\mathrm{Fe}^{-} \mathrm{oxy}$-hydroxides during weathering and soil formation process was also found by other authors (Buccianti et al., 2015; Cabral Pinto et al., 2017;

271 Caillaud et al., 2009; Hamon et al., 2004; Rate, 2018). Organics related elements

272 (e.g., C. org, S, Ba) are related to soils forming from $\epsilon^{-1}$ and $\epsilon^{-2}$ formation and near the HTP and HYA mining areas. Fine-grain minerals in soils formed from mudstones

274 are conducive to the accumulation of organic matters. Another reason could be that 275 lower temperatures in these higher altitude areas limit organic turnover, which results in their increased accumulation even under conditions of smaller 


\subsection{Enrichment and depletion of PTMs in soils} related to parent materials determined by S/R. Fig. 8 is presented to help to highlight the differences. Values parent materials, and the amount of depletion is particularly significant in soils different formations. obvious enrichment or depletion. Soils overlying mudstone and sandstone formations $(\epsilon-1, \epsilon-2,0, S)$ are depleted in $\mathrm{K}$ and $\mathrm{Mg}$; and enriched in $\mathrm{Ca}, \mathrm{As}, \mathrm{Cd}, \mathrm{Hg}, \mathrm{Pb}$ and S. Soils overlying carbonic formations $(€-3, \mathrm{D}, \mathrm{C}-1, \mathrm{~T}-1, \mathrm{~T}-2, \mathrm{~J})$ are depleted in $\mathrm{Ca}, \mathrm{Na}, \mathrm{Sr}$ and $\mathrm{Mg}$ (in T-2) ; and enriched in nearly all other elements. The depletion 
during surface processes. While, the enrichment of $\mathrm{Fe}$ is due to its precipitation as oxy-hydroxides, whilst the enrichment of PTMs (As, Cd, Cr, Cu, Hg, Ni, Pb, $\mathrm{Zn}$ ) in the soils may be resulted by their coprecipitation and/or adsorption by Fe oxy-hydroxides (Buccianti et al., 2015; Cabral Pinto et al., 2017; Caillaud et al.,

2009; Hamon et a1., 2004; Rate, 2018). minerals is apparent and due to their high concentrations in the ore samples. Soils overlying HTP and HYA are enriched in $\mathrm{Al}, \mathrm{K}, \mathrm{Ba}, \mathrm{Cr}, \mathrm{Hf}, \mathrm{Nb}, \mathrm{Ni}, \mathrm{Rb}, \mathrm{Ta}, \mathrm{Th}, \mathrm{U}, \mathrm{Zr}$ due to their coprecipitation during weathering.

\subsection{Risk evaluation} risk screening values for soil contamination of agricultural land of the People's Republic of China (PRC) are listed in Table 9. If the concentration of PTMs in agriculture land is lower than or equal to the risk screening values, the ecological risk of soils and environmental quality of agricultural products grown on the land are low, whereas if the concentration of PTMs in agriculture land is higher than

317 the risk screening values, the ecological risks for the soils and agricultural products grown in them. Where the later is the casing soil environmental monitoring and collaborative testing of agricultural products should be executed (Ministry of 
Ecology and Environment of The People' s Republic of China, 2018).

Most of the soil samples with the PTMs values exceed the risk screening values are overlying the carbonate formations, basalt formations and near the HTP and HYA mining areas. For As, the samples mainly overlying $\epsilon-3, \mathrm{C}, \mathrm{T}-1, \mathrm{~T}-2$, HTP and HYA and with a few samples in $€-1$ and $€-2$. For $C d$, the samples are mainly overlying C, T-1, T-2, HTP and HYA. For $\mathrm{Cr}$, the samples are mainly overlying $\mathrm{T}-1, \mathrm{~T}-2$, Ba-1and Ba-2. For $\mathrm{Cu}$, the samples are mainly overlying $€-3$, $\mathrm{T}-1$, HTP, HYA and Ba-1. For $\mathrm{Ni}$, the samples are mainly overlying $€-3, \mathrm{C}-1, \mathrm{~T}-1, \mathrm{~T}-2, \mathrm{Ba}-1$ and $\mathrm{Ba}-2$. For $\mathrm{Pb}$ and Zn, the samples are mainly overlying $€-3$, HTP and HYA. Only two soil samples in study area are exceed the risk screening value of $\mathrm{Hg}$, one overlies $\mathrm{C}-1$, the other overlies $6-3$. As discussed previously, high levels of PTMs in soil overlying basalt formations $(\mathrm{Cr}, \mathrm{Cu}, \mathrm{Ni})$, and near HTP and HYA ( $\mathrm{As}, \mathrm{Cd}, \mathrm{Cu}, \mathrm{Pb}, \mathrm{Zn}$ ) are due to their high concentrations in the bedrocks, whilst soils inherited their geochemistry characteristics from parent materials. For soils overlying carbonate formations high levels are due to the coprecipitation ( $\mathrm{As}, \mathrm{Cd}, \mathrm{Cr}, \mathrm{Cu}, \mathrm{Hg}, \mathrm{Ni}, \mathrm{Pb}, \mathrm{Zn}$ ) and/or adsorption by $\mathrm{Fe}^{-} \mathrm{oxy}$-hydroxides under the influence of high $\mathrm{pH}$ values (e.g. $\mathrm{Cr}$ and $\mathrm{Ni}$. The soils sample forming on carbonate rocks, basalts and in mining areas have higher PTMs content and higher ecological risk which has also been found by other researchers (Barsby et a1., 2012; Cabral Pinto et al., 2017; Cheng, 2016; Cox et a1., 2017; Goldhaber et a1., 2009; Tolosana-Delgado and McKinley, 2016; Wang et a1. , 2015; Zhang et a1., 2002).

The index of geo-accumulation $\left(\mathrm{I}_{\text {geo }}\right)$ and enrichment factors $(\mathrm{EF})$ which are used 
widely to assess 1evels and origins of contamination (Barbieri, 2016; Bern et al., 2019; Cevik et al., 2009; Feng et al., 2011; Ghrefat et al., 2011; Liénard et al., 2014; Thiombane et al., 2019; Zhang et al., 2014). Reimann and Caritat (2000; 2005) and Sucharovà et al (2012) have proposed that these indices cannot be used as rigorous, objective or sensitive tools to detect or prove anthropogenic impact on the environment due to the flaws of $\mathrm{EF}$ and $\mathrm{I}_{\mathrm{geo}}$, these indexes are still considerable tools to assess levels of contamination their possible origins by choosing proper background values and comparing to other evidence.

The $I_{\text {geo }}$ and $E F$ are calculated using the following equations (Eq. 1 and 2):

$$
\text { (1) } \mathrm{I}_{\text {gео }}=\log 2\left[\frac{c_{n}}{1.5 B_{n}}\right]
$$

where $C_{n}$ is the concentration for a given PTM and $B_{n}$ is the background level of that PTM in the soil (Müller, 1969). The median values of PTMs in deep soil from the 1:250000 scale land quality geochemical in Baoshan area, as are much less likely to be affected by human activities (Cheng et al., 2014c) and geochemical background baseline of China, the median values of deep soil of China Geochemical Baseline project (Wang et al, 2016) were used as $B_{n}$ for calculation separately.

(2) $\mathrm{EF}=\frac{(\text { Metal } / R E)_{\text {soil }}}{(\text { Metal } / R E)_{\text {rock }}}$

Where EF is the enrichment factor for a given PTM, subscript "soil” indicates surface soil concentration for that PTM, subscript “rock” indicates that PTM in the bedrocks, and “RE" is the concentration of reference element. Aluminum is choosing as RE for its non-mobile nature during weathering (Balls et al., 1997; 
Cabral Pinto et a1., 2017; Ryan and Windom, 1988; Sinex and Wright, 1988).

The results of $I_{\text {geo }}$ with the value $>2$ are considered to be contaminated, according to previous studies (Müller, 1969; Odewande and Abimbola, 2008). The numerical results are shown in Table 9. The results of $\mathrm{I}_{\text {geo }}$ for $\mathrm{Cd}, \mathrm{Pb}, \mathrm{Zn}$ based on local background levels (median values of deep soil from the 1:250000 scale land quality geochemical in Baoshan area) and geochemical background baseline of China (the median values of deep soil of China Geochemical Baseline project) do not show much difference. The soils with As, Pb and Zn contamination occur mainly near HTP and HYA mining areas; the soils with $\mathrm{Cd}$ contamination mainly from the $\mathrm{C}, \mathrm{T}-1$ and $\mathrm{T}-2$ formations and soils near HTP and HYA mining areas. While, for elements Hg, Ni and $\mathrm{Cu}$ show different results base on the $\mathrm{B}_{\mathrm{n}}$. Use local background as $\mathrm{B}_{\mathrm{n}}$ may underestimate the PTMs contamination in where there is a high geological background of PTMs. By conducting a comparison with larger-scale datasets as background when calculating this is a better way to solve the problem.

Normally, the value of $0.5<\mathrm{EF}<1.5$ is taken as an indicator that PTMs are entirely provided from natural contribution such as weathering, and a value of $\mathrm{EF}>1.5$ is considered to indicate the PTMs are delivered from non-crustal materials, for example, biota and/or pollution drainage (Zhang and Liu, 2001). Combine the contamination categories most authors used (Addo et al., 2012; Barbieri, 2016; Loska et al., 2003), soils with $\mathrm{EF}$ value $>2$ are thought to be moderately contaminated and caused by anthropogenic activities in this study. The results are shown in Table 9, show that, soils with $\mathrm{As}, \mathrm{Cd}$, $\mathrm{Hg} \mathrm{Pb}$ contamination are mainly overlying formations 
of $\epsilon-1, \epsilon-2,0, \mathrm{~S}$ and $\mathrm{Ba}-2$. Those contaminate sample locations according to $\mathrm{EF}$ value are mainly near mining areas (Fig. 3), and this may indicate that the mining activities led to soil contamination. While no contamination was found in the soils near HTP and HYA mining areas according to EF results. This is due to the high concentration of PTMs (As, $\mathrm{Cd}, \mathrm{Hg}, \mathrm{Pb}, \mathrm{Zn}$ ) in ores. As such, the EF calculated for soil-rock in high geological background areas may underestimate the contamination. Assessment the concentration of bioavailable of PTMs in soils is vital important in evaluate soil quality (Barbieri, 2016; Barsby et al., 2012; Cox et al., 2017; Jackson et al., 2016; Palmer et al., 2014; Prathumratana et al., 2018; Zhang et al., 2018). For the reason, PTMs in soil from anthropogenic origins tend to be more mobile, hence more bio-available than for pedogenic or 1ithogenic ones (Basta et al., 2005; Kuo et al., 1983; Nannoni et a1., 2011). To find the biological risk of PTMs, the extractable $\mathrm{Cd}, \mathrm{Pb}$ and $\mathrm{As}$ of soil samples were analyzed, the results are showed in Table 10. Extractable As is not discussed in this paragraph, due to their content in most of the soils being lower than detection limits. The soils overlying HTP and HYA have higher extractable $\mathrm{Cd}$ and $\mathrm{Pb}$ than other soils (Table 10), which may indicate the mining activities contributions to the surface soils contaminations near the mining areas.

Based on the soil environmental assessment methods used above, we suggest that the monitoring of soils formed on carbonate rocks and basalts, and especially mineralization formations and mining areas should be implemented in this study area. 


\section{Conclusions}

This research demonstrates enrichment of potentially toxic metals (PTMs) (As,

$\mathrm{Cd}, \mathrm{Cr}, \mathrm{Cu}, \mathrm{Hg}, \mathrm{Ni}, \mathrm{Pb}, \mathrm{Zn}$ ) in soils related to their parent materials. The enrichment in soils may be due to the removal of mobile elements (e.g., Ca, Na, Mg and $\mathrm{Sr}$ ), and coprecipitation ( $\mathrm{As}, \mathrm{Cd}, \mathrm{Cr}, \mathrm{Cu}, \mathrm{Hg}, \mathrm{Ni}, \mathrm{Pb}, \mathrm{Zn}$ ) and/or adsorption by Fe-oxy-hydroxides (Cr, Ni) under the influence of high $\mathrm{pH}$ values during soils formation. However, anthropogenic contamination is also possible for soil near mining areas. The soils forming from carbonate rocks, basalts, and especially mineralization formations have a higher PTMs concentration, that exceeds risk screening values for soil contamination of agricultural land of China. Ecological monitoring should be implemented on those soils in the study area. The geo-accumulation index $\left(\mathrm{I}_{\text {geo }}\right)$ and enrichment factor $(\mathrm{EF})$ methods may underestimate PTMs contamination in where there is a high geological background of PTMs, and by conducting a comparative with a larger-scale background dataset when calculating is the better way to solve the problem.

\section{Acknowledgements}

The authors would like to thank the funding provided by the China Geological 
from "National Earth System Science Data Sharing Infrastructure, National Science \& Technology Infrastructure of China. (http://www. geodata.cn)". Finally, the authors would like to express our sincere thanks to the editor and the anonymous reviewers for their critical and constructive comments and suggestions.

\section{References}

Addo, M., Darko, E., Gordon, C., Nyarko, B. J. B., Gbadago, J., Nyarko, E., Affum, H., Botwe, B., 2012. Evaluation of Heavy Metals Contamination of Soil and Vegetation in the Vicinity of a Cement Factory in the Volta Region, Ghana. International Journal of Science and Technology 2, 40-50.

Aitchison, J., 1981. A new approach to null correlations of proportions. Journal of the International Association for Mathematical Geology 13, 175-189.

Aitchison, J., 1982. The Statistical Analysis of Compositional Data. Technometrics 30, 120-121.

Aitchison, J., 1986. The Statistical Analysis of Compositional Data. Chapman \& Ha11, London.

Akopyan, K., Petrosyan, V., Grigoryan, R., Melkomian, D. M., 2018. Assessment of residential soil contamination with arsenic and lead in mining and smelting towns of northern Armenia. Journal of Geochemical Exploration. 184, 97-109.

Alvarezayuso, E., Garciasanchez, A., 2003. Sepiolite as a feasible soil additive for the immobilization of cadmium and zinc. Science of The Total Environment 305, $1-12$. 

$434-450$. in Scottish Estuarine and Coastal Sediments. Marine Pollution Bulletin 34, 42-50.

Barsby, A., McKinley, J. M., Ofterdinger, U., Young, M., Cave, M. R., Wragg, J. ,

Basta, N. T., Ryan, J.A., Chaney, R. L., 2005. Trace element chemistry in residual-treated soil: key concepts and metal bioavailability. J Environ Qual 34, 49-63. of Soil Science 57, 200-213. 
of Greek Ophiolitic Environments Using Statistical Analysis. Environmental Processes 2, 5-21.

$$
\text { Bonifacio, E., Falsone, G., Piazza, S., 2010. Linking Ni and Cr concentrations }
$$
to soil mineralogy: does it help to assess metal contamination when the natural background is high? Journal of Soils and Sediments 10, 1475-1486.

Boogaart, K. G. V. D., Tolosana-Delgado, R., 2013. Analyzing Compositional Data with R. Use R, 73-93.

Buccianti, A., Lima, A., Albanese, S., Cannatelli, C., Esposito, R., De Vivo, B., 2015. Exploring topsoil geochemistry from the CoDA (Compositional Data Analysis) perspective: The multi-element data archive of the Campania Region (Southern Italy). Journal of Geochemical Exploration 159, 302-316.

Cabral Pinto, M. M. S., Silva, M. M. V. G., Ferreira da Silva, E. A., Dinis, P.A., Rocha, F., 2017. Transfer processes of potentially toxic elements (PTE) from rocks to soils and the origin of PTE in soils: A case study on the island of Santiago (Cape Verde). Journal of Geochemical Exploration 183, 140-151.

Cabral-Pinto, M. M. S., Marinho-Reis, A. P., Almeida, A., Ordens, C. M., Silva, M. M., Freitas, S., Simoes, M. R., Moreira, P. I., Dinis, P. A., a Diniz, M. L., da Silva, E. A. F., de Melo, M. S. C., 2018. Human predisposition to cognitive impairment and its relation with environmental exposure to potentially toxic elements. Environmental geochemistry and health, 40(5), 1767-1784.

Cabral-Pinto, M. M., Inácio, M., Neves, 0., Almeida, A. A., Pinto, E., Oliveiros, B., da Silva, E. A. F., 2019a. Human Health Risk Assessment Due to Agricultural 
Activities and Crop Consumption in the Surroundings of an Industrial Area. Exposure and Health, 1-12.

\author{
Cabral-Pinto, M. M. S., Ordens, C. M., de Melo, M. T. C., Inácio, M., Almeida,
} A., Pinto, E., da Silva, E. A. F. 2019b. An inter-disciplinary approach to evaluate human health risks due to long-term exposure to contaminated groundwater near a chemical complex. Exposure and Health, 1-16.

Caillaud, J., Proust, D., Philippe, S., Fontaine, C., Fialin, M., 2009. Trace metals distribution from a serpentinite weathering at the scales of the weathering profile and its related weathering microsystems and clay minerals. Geoderma 149, 199-208.

Cevik, F., Goksu, M.Z., Derici, 0. B., Findik, 0., 2009. An assessment of metal pollution in surface sediments of Seyhan dam by using enrichment factor, geoaccumulation index and statistical analyses. Environ Monit Assess 152, 309-317. Chayes, F., 1960. On correlation between variables of constant sum. Revista De Economía Del Caribe 1996, 42-78.

Cheng, H., Li, M., Xie, X., Yang, Z., Li, C., 2014a. Exploring China: Environment and Resources. Journal of Geochemical Exploration 139, 1-3.

Cheng, H., Li, M., Zhao, C., Li, K., Peng, M., Qin, A., Cheng, X., 2014b. Overview of trace metals in the urban soil of 31 metropolises in China. Journal of Geochemical Exploration 139, 31-52.

Cheng, H. X., Li, K., Li, M., Yang, K., Liu, F., Cheng, X. M., 2014c. Geochemical background and baseline value of chemical elements in urban soil in China. Earth 
Science Frontiers 21, 265-306. (In Chinese with English abstract)

Cheng, X. M., 2016. Geochemical Behavior and Risk Analysis for heavy Elements in Soil Profiles with Different Parent Material, Yunnan Province, China. China University of Geosciences, Beijing. (In Chinese with English abstract) Cheng, Z., Xie, X., Yao, W., Feng, J., Zhang, Q., Fang, J., 2014d. Multi-element geochemical mapping in Southern China. J Geochem Explor 139, 183-192.

$$
\text { Chiu, Y.P., Li, D.W., Shiau, Y.C., 2016. Study on Heavy Metal Characteristics }
$$
of Soil in Phosphorus Tail. Journal of Residuals Science \& Technology 2, 40-50. Cicchella, D., De, V. B., Lima, A., Albanese, S., Mc, G. R.A. R., Parrish, R. R., 2008. Heavy metal pollution and $\mathrm{Pb}$ isotopes in urban soils of Napoli, Italy. Geochemistry Exploration Environment Analysis 8, 103-112.

Cox, S.F., Rollinson, G., McKinley, J. M., 2017. Mineralogical characterisation to improve understanding of oral bioaccessibility of $\mathrm{Cr}$ and $\mathrm{Ni}$ in basaltic soils in Northern Ireland. Journal of Geochemical Exploration 183, 166-177.

CGS, 2005. Technical requirements for sample analysis for eco-geochemical evaluation (DD2005-03), in: China Geological Survey (Ed.), Beijing. (In Chinese) CGS, 2014. Specification for multi-purpose regional geochemical survey (DD/T 0258-2014), in: China Geological Survey (Ed.), Beijing. (In Chinese) Dong, M., Dong, G., Mo, X., Santosh, M., Zhu, D., Yu, J., Nie, F., Hu, Z., 2013. Geochemistry, zircon $\mathrm{U}-\mathrm{Pb}$ geochronology and $\mathrm{Hf}$ isotopes of granites in the Baoshan Block, Western Yunnan: Implications for Early Paleozoic evolution along the Gondwana margin. Lithos 179, 36-47. 
Geology 35, 279-300.

Ettler, V., 2016. Soil contamination near non-ferrous metal smelters: A review. and adjacent estuaries, China. 92, 1185-1197.

Smith, D.B., 2009. A regional soil and sediment geochemical study in northern 
estimation of heavy metal background concentrations in soils. Global Biogeochemical Cycles 18, 1-6.

Hamzeh, M. A., Aftabi, A., Mirzaee, M., 2011. Assessing geochemical influence of traffic and other vehicle-related activities on heavy metal contamination in urban soils of Kerman city, using a GIS-based approach. Environ Geochem Health 33, $577-594$.

Ryan, J. D., Windom, H. L., 1988. A Geochemical and Statistical Approach for Assessing Metal Pollution in Coastal Sediments. Springer Berlin Heidelberg, 47-58. Jackson, C.E., McKinley, J.M. , Ofterdinger, U., Fogarty, D., Atkinson, P.M. , Palmer, S., 2016. Investigating relations between environmental toxins in Northern Irish soils and streams and Chronic Kidney Disease prevalence. Applied Geochemistry $75, \quad 236-246$.

Kelepertzis, E., Galanos, E., Mitsis, I., 2013. Origin, mineral speciation and geochemical baseline mapping of $\mathrm{Ni}$ and $\mathrm{Cr}$ in agricultural topsoils of Thiva Valley (central Greece). Journal of Geochemical Exploration 125, 56-68.

Kuo, S., HEILMAN, P.E., BAKER, A.S., 1983. Distribution and forms of copper, zinc, cadmium, iron, and manganese in soils near a copper smelter. Soil Science 135, $101-109$.

Leifeld, J., Bassin, S., Fuhrer, J., 2005. Carbon stocks in Swiss agricultural soils predicted by land-use, soil characteristics, and altitude. Agriculture, Ecosystems \& Environment 105, 255-266.

$$
\text { Li, D., Chen, Y., Hou, K., Lu, Z., Cui, D., 2015. Detrital zircon record of }
$$


580

581

582

583

584

585

586

587

588

589

590

591

592

593

594

595

596

597

598

599

600

601

Paleozoic and Mesozoic meta-sedimentary strata in the eastern part of the Baoshan

block: Implications of their provenance and the tectonic evolution of the southeastern margin of the Tibetan plateau. Lithos 227, 194-204.

Li, M., Xi, X., Xiao, G., Cheng, H., Yang, Z., Zhou, G., Ye, J., Li, Z., 2014a.

National multi-purpose regional geochemical survey in China. Journal of Geochemical Exploration 139, 21-30.

Li, X. H., Cheng, H.X., Zhao, C. D., Xu, X. B., 2010. Mercury contamination in the topsoil and subsoil of urban areas of Beijing, China. Bull Environ Contam Toxicol $85, \quad 224-228$.

Li, Z., Ma, Z., van der Kuijp, T. J., Yuan, Z., Huang, L., 2014b. A review of soil heavy metal pollution from mines in China: pollution and health risk assessment.

Sci Total Environ 468-469, 843-853.

Liénard, A., Brostaux, Y., Colinet, G., 2014. Soil contamination near a former $\mathrm{Zn}-\mathrm{Pb}$ ore-treatment plant: Evaluation of deterministic factors and spatial structures at the landscape scale. Journal of Geochemical Exploration 147, 107-116. Loska, K., Wiechula, D., Barska, B., Cebula, E., Chojnecka, A., 2003. Assessment of arsenic enrichment of cultivated soils in Southern Poland. Polish Journal of Environmental Studies 12, 187-192.

Luo, X. S., Yu, S., Zhu, Y.G., Li, X. D., 2012. Trace metal contamination in urban soils of China. Sci Total Environ 421-422, 17-30.

Ministry of Land and Resources of the People's Republic of China, 2014. Code of Geochemical Rock Survey of China (DZ/T 0248-2014). (In Chinese) 

mobility of heavy elements in soils of a mining area in northern Kosovo. Geoderma 161, $63-73$. concentrations in urban soil of Ibadan metropolis, southwestern Nigeria. Environ Geochem Health 30, 243-254. factors controlling the distribution and oral bioaccessibility of nickel, vanadium and chromium in soil. Applied Geochemistry 51, 255-267. and Applications. John Wiley \& Sons. analysis on the simplex. Stochastic Environmental Research and Risk Assessment 15, 
624

625

626

627

628

629

630

631

632

633

634

635

636

637

638

639

640

641

642

643

644

645

384-398.

Pinto, M. M. S. C., Silva, M. M., Neiva, A. M. R., 2004. Pollution of Water and Stream

Sediments Associated with the Vale De Abrutiga Uranium Mine, Central Portugal. Mine Water and The Environment 23, 66-75.

Poňavič, M., Wittlingerová, Z., Čoupek, P., Buda, J., 2018. Soil geochemical mapping of the central part of Prague, Czech Republic. Journal of Geochemical Exploration 187, 118-130.

Prathumratana, L., Kim, R., Kim, K.W., 2018. Lead contamination of the mining and smelting district in Mitrovica, Kosovo. Environmental geochemistry and health, $1-12$.

Purswani, E., Pathak, B., 2018. Assessment of soil characteristics in different land-use systems in Gandhinagar, Gujarat. Proceedings of the International Academy of Ecology and Environmental Sciences 8(3): 162-171

Rate, A.W., 2018. Multielement geochemistry identifies the spatial pattern of soil and sediment contamination in an urban parkland, Western Australia. Sci Total Environ 627, 1106-1120.

Sinex, S. A., Wright, D.A., 1988. Distribution of trace metals in the sediments and biota of Chesapake Bay. Mar Pollut Bull 19, 425-431.

Tashakor, M., Zuhairi, W. Y.W., Mohamad, H., Ghani, A. A., 2014. Geochemical characteristics of serpentinite soils from Malaysia. Malaysian Journal of Soil Science 18, 35-49.

Thio-Henestrosa, S., Martin-Fernandez, J. A., 2006. Detailed guide to CoDaPack: 
646

647

648

650

651

652

654

655

656

657

658

659

660

661

662

663

664

665

666

667

A freeware compositional software. Geological Society London Special Publications 264, 101-118.

Thiombane, M., Di Bonito, M., Albanese, S., Zuzolo, D., Lima, A., De Vivo, B., 2019. Geogenic versus anthropogenic behaviour and geochemical footprint of Al, Na, $\mathrm{K}$ and $\mathrm{P}$ in the Campania region (Southern Italy) soils through compositional data analysis and enrichment factor. Geoderma 335, 12-26.

Tolosana-Delgado, R., McKinley, J., 2016. Exploring the joint compositional variability of major components and trace elements in the Tellus soil geochemistry survey (Northern Ireland). Applied Geochemistry 75, 263-276.

Wang, X., Liu, X., Han, Z., Zhou, J., Xu, S., Zhang, Q., Chen, H., Bo, W., Xia, X., 2015. Concentration and distribution of mercury in drainage catchment sediment and alluvial soil of China. Journal of Geochemical Exploration 154, 32-48.

Wang X. Q., Zhou J., Xu S.F., Chi Q. H., Nie L. S., ZhangB. M., YA0 W. S., Wang Wei., Liu., H. L., Liu D. S., Han Z.X., Liu Q. Q., 2016. China soil geochemical baselines networks: Data characteristics. Geology in China, 43(5): 1469-1480. (in Chinese with English abstract)

Wang, Y., Xing, X., Cawood, P. A., Lai, S., Xia, X., Fan, W., Liu, H., Zhang, F., 2013. Petrogenesis of early Paleozoic peraluminous granite in the Sibumasu Block of SW Yunnan and diachronous accretionary orogenesis along the northern margin of Gondwana. Lithos 182-183, 67-85.

Wang, Y., Zhang, A., Fan, W., Peng, T., Zhang, F., Zhang, Y., Bi, X., 2010. Petrogenesis of late Triassic post-collisional basaltic rocks of the Lancangjiang 
668

669

670

672

673

674

676

677

678

679

680

681

682

683

684

685

687

688

689

tectonic zone, southwest China, and tectonic implications for the evolution of the eastern Paleotethys: Geochronological and geochemical constraints. Lithos 120, $529-546$.

Wiesmeier, M., Hübner, R., Barthold, F., Spörlein, P., Geuß, U., Hangen, E. , Reisch1, A., Schilling, B., von Lützow, M., Kögel-Knabner, I., 2013. Amount, distribution and driving factors of soil organic carbon and nitrogen in cropland and grassland soils of southeast Germany (Bavaria). Agriculture, Ecosystems \& Environment 176, 39-52.

Zhang, H., Chen, J., Li, Z., Yang, G., Li, D., 2014. Anthropogenic mercury enrichment factors and contributions in soils of Guangdong Province, South China. Journal of Geochemical Exploration 144, 312-319.

Zhang, H. , Luo, Y., Makino, T., Wu, L., Nanzyo, M., 2013. The heavy metal partition in size-fractions of the fine particles in agricultural soils contaminated by waste water and smelter dust. J Hazard Mater 248-249, 303-312.

$$
\text { Zhang, J., Li, H., Zhou, Y., Dou, L., Cai, L., Mo, L., You, J., } 2018 .
$$
Bioavailability and soil-to-crop transfer of heavy metals in farmland soils: A case study in the Pearl River Delta, South China. Environ Pollut 235, 710-719.

Zhang, J., Liu, C. L., 2001. Riverine Composition and Estuarine Geochemistry of Particulate Metals in China-Weathering Features, Anthropogenic Impact and Chemical Fluxes. Estuarine, Coastal and Shelf Science 54, 1051-1070.

Zhang, X.P., Wei, D., Yang, X. M. , 2002. The background concentrations of 13 soil trace elements and their relationships to parent materials and vegetation in Xizang 
690 (Tibet), China. Journal of Asian Earth Sciences 21, 167-174. 

Baoshan area. Table 2 Brief description of soils sampled in the Baoshan area. Table 3 Analytical methods and detection limits.

Table 4 Average concentrations of major (wt.\%) and trace elements $(\mu \mathrm{g} / \mathrm{g})$ for geological formations in the Baoshan area.

Table 5 Variance explained by each principal component and component loadings for PC1-PC4 of rock/ore samples. Table 6 Average concentrations of major (wt.\%) and trace elements ( $\mu \mathrm{g} / \mathrm{g}$ ) for soils developed on different geological formations in the Baoshan area.

Table 7 Variance explained by each principal component and component loadings for PC1-PC6 of soil samples.

Table 8 Level of enrichment/depletion of chemical elements from the Baoshan soils from the different geological formations, relatively to the respective rocks, determined by Median soil content/Median underlying rock content.

Table 9 Numbers of contaminated soil samples from different geological formations in the Baoshan area.

Table 10 Average concentrations of extractable $\mathrm{As}, \mathrm{Cd}$ and $\mathrm{Pb}(\mu \mathrm{g} / \mathrm{g})$, and their percentage to total content in the soils developed on different geological formations in the Baoshan.

711 Fig. 1 Contour maps of altitude, average surface soil $(0 \mathrm{~cm})$ temperature and annual rainfall for 
study area.

Fig. 2 Simplified land-use (a) and soil-type (b) maps of study area.

714 Fig. 3 Simplified tectonic map of Yunnan Sanjiang area.

715 Fig. 4 Simplified geological and mineral deposits map of study area.

716 Fig. 5 Sample locations in each geological formation and near the HTP and HYA mining areas in 717 this study.

718 Fig. 6 Biplots of the principal components for the clr-transformed whole composition of rock and

719 ore samples, with parallel plots for grouping of rock/ ore samples by different geological 720 formations in the PC1-PC2 (a) and PC1-PC3 (b) principal component space.

721 Fig. 7 Biplots of the principal components for the clr-transformed whole composition of soil 722 samples, with parallel plots for grouping of soil samples by overlying different geological 723 formations in the PC1-PC2 (a) and PC2-PC3 (b) principal component space.

724 Fig. 8 Median values of elements ratio (soil/rock) derived from the different geological formations to reflect the PTMs enrichment and depletion in soils related to their bedrocks. 
Table 1 Brief description of sampled rocks and their underlying geological formations in the Baoshan area.

\begin{tabular}{|c|c|c|c|c|c|c|}
\hline No & $\begin{array}{c}\text { Sample } \\
\text { Name }\end{array}$ & $\begin{array}{l}\text { Formation } \\
\text { Name }\end{array}$ & Sampled geological formation and deposit description* & Age/formation & Outcrop locations & Sampled rock (number) \\
\hline 1 & $\epsilon-1-R$ & $\epsilon-1$ & $\begin{array}{l}\text { Baoshan formation: Gray, yellow-green shale, sandstone containing limestone, argillaceous limestone; The } \\
\text { lower section of Liushui formation: Yellow-green, grayish yellow siltstone, mudstone with argillaceous } \\
\text { limestone }\end{array}$ & $\epsilon_{3} b ; \epsilon_{3} l^{1}$ & $\begin{array}{l}\text { The northernmost part of the } \\
\text { middle line in the study area }\end{array}$ & Mudstone (9); limestone (1) \\
\hline 2 & $\epsilon-2-R$ & $\epsilon-2$ & $\begin{array}{l}\text { Upper section of Shahechang formation: shale and siltstone; Hetaoping formation: grayish green slate; The } \\
\text { upper section of the Shuangmai formation: dark green rhythmic slate }\end{array}$ & $\begin{array}{c}\epsilon_{3 s^{2}} ; \epsilon_{3} h ; \\
\epsilon_{1-2 s} h^{3}\end{array}$ & $\begin{array}{l}\text { North Central of the study area } \\
\text { and northwest of Baoshan city }\end{array}$ & Mudstone (9); phyllite (2) \\
\hline 3 & $\epsilon-3-R$ & $\epsilon-3$ & The upper section of Baoshan formation: shale, limestone with sandstone & $\epsilon_{3} b^{2}$ & Central part of the study area & Limestone (8); siliceous limestone (2) \\
\hline 4 & $\mathrm{O}-\mathrm{R}$ & $\mathrm{O}$ & Mantang formation: grayish white sandstone, shale (slate) & $\mathrm{O}_{1} m$ & $\begin{array}{l}\text { Central north and south part of } \\
\text { the study area }\end{array}$ & Sandstone (2); mudstone (4); quartz sandstone (4) \\
\hline 5 & S-R & $\mathrm{s}$ & $\begin{array}{l}\text { Upper Renheqiao formation: light gray reticulated limestone; Lower Renheqiao formation: Black graptolite } \\
\text { shale }\end{array}$ & $\mathrm{S}_{1} r ; \mathrm{S}_{2} r$ & $\begin{array}{l}\text { Distributed in the middle as } \\
\text { narrow strip of the study area }\end{array}$ & Shale (7); limestone (3) \\
\hline 6 & D-R & $\mathrm{D}$ & $\begin{array}{l}\text { Shabajiao formation, Wangjiacun formation and Xiangyangsi formation are combined or not divided: sandy } \\
\text { dolomite, argillaceous limestone, sandy limestone; Heyuanzhai formation: argillaceous limestone, pimple } \\
\text { limestone; Dazhaimen formation: argillaceous limestone and calcareous mudstone }\end{array}$ & $\mathrm{D}_{1} ; \mathrm{D}_{2} h y ; \mathrm{D}_{3} d$ & $\begin{array}{l}\text { Widely distributed in the } \\
\text { central south and northwest }\end{array}$ & Limestone (9); dolomite (1); siltstone (1) \\
\hline 7 & C-R & $\mathrm{C}$ & $\begin{array}{l}\text { Pumenqian formation and Xiangshan formation are combined or not divided: Olitic limestone, chert limestone, } \\
\text { mud limestone with argillaceous limestone in its lower part; Dingjiazhai formation: gray mudstone with } \\
\text { argillaceous limestone, sandstone and conglomerate }\end{array}$ & $\mathrm{C}_{1} ; \mathrm{C}_{3} d$ & Midwest and northwest & Limestone (8); siliceous limestone (1); mudstone (1) \\
\hline 8 & $\mathrm{~T}-1-\mathrm{R}$ & T-1- & The upper section of Dashuitang formation: limestone, chert limestone & $\mathrm{T}_{3} d^{2}$ & $\begin{array}{l}\text { Widely distributed in the west } \\
\text { and east part of the study area }\end{array}$ & Limestone (8); dolomitic limestone (1); dolomite (1) \\
\hline 9 & $T-2 R$ & $\mathrm{~T}-2$ & Hewanjie formation: dolomite & $\mathrm{T}_{2} h$ & $\begin{array}{l}\text { Widely distributed in the west } \\
\text { and east part of the study area }\end{array}$ & Dolomite (10) \\
\hline 10 & $\mathrm{~J}-\mathrm{R}$ & $\mathrm{J}$ & Liuwan formation: limestone, shale and shell limestone & $\mathrm{J}_{2} l$ & $\begin{array}{l}\text { Distributed in the west of the } \\
\text { study area as long strips }\end{array}$ & Limestone (7); siliceous limestone (1); sandstone (2) \\
\hline 11 & Ba-1-R & Ba-1 & Woniusi formation: dense and amygdaloid basalt with limestone lens & $\mathrm{C}_{3} w$ & $\begin{array}{l}\text { Northwest and northeast of the } \\
\text { study area }\end{array}$ & Basalt (10) \\
\hline 12 & Ba-2-R & $\mathrm{Ba}-2$ & The upper section of Mengjia formation: Basalt & $\mathrm{J}_{2} m^{2}$ & Southwest of the study area & Basalt (10) \\
\hline 13 & HTP-O & HTP & Hetaoping Cu-Pb-Zn deposit. Main ore minerals: Galena, Chalcopyrite, Sphalerite, Pyrite, Pyrrhotite. & HTP & $\begin{array}{l}\text { The northernmost part of study } \\
\text { area }\end{array}$ & (Galena) (Chalcopyrite) Sphalerite (10) \\
\hline 14 & HYA-O & HYA & $\begin{array}{l}\text { Heiyanao Fe-Cu-Pb-Zn deposit. Main ore minerals: Pyrite, Chalcopyrite, Pyrrhotite, Magnetite, Hematite, } \\
\text { Galena, Sphalerite. }\end{array}$ & HYA & $\begin{array}{l}\text { The northernmost part of study } \\
\text { area }\end{array}$ & $\begin{array}{l}\text { (Galena) (Chalcopyrite) Sphalerite (5); chalcopyrite } \\
\text { (1); pyrite (1); magnetite (3) }\end{array}$ \\
\hline
\end{tabular}


Table 2 Brief description of soils sampled in the Baoshan area.

\begin{tabular}{|c|c|c|c|c|c|}
\hline No. & Sample Name & Soil type and soil characteristic description & Average height & Land use of sampled soils (number) & Under formation \\
\hline 1 & $\epsilon-1-S$ & $\begin{array}{l}\text { Yellow brown soils/ dark yellow brown soils. Black brown, brown and earthy yellow fine } \\
\text { grain loam. }\end{array}$ & $2470 \mathrm{~m}$ & Forest land (10) & $\epsilon-1$ \\
\hline 2 & $\epsilon-2-\mathrm{S}$ & Brown/yellow brown soils. Brown, earthy yellow fine grain loam. & $2672 \mathrm{~m}$ & Forest land (11) & $\epsilon-2$ \\
\hline 3 & $\epsilon-3-S$ & Yellow-red soils/ Acid purple soils. Red, earthy yellow, fine-medium grain loam. & $1989 \mathrm{~m}$ & Forest land (3); Shrubland (7) & $\epsilon-3$ \\
\hline 4 & $\mathrm{O}-\mathrm{S}$ & Red soils/ dry red soils/ yellow red soils. Brown, earthy yellow fine-medium grain loam. & $1473 \mathrm{~m}$ & Cultivated land/Dry land (6); Shrubland (4) & $\mathrm{O}$ \\
\hline 5 & S-S & Yellow red soils/ red soils. Earthy yellow, red and brown fine-medium grain loam. & $1876 \mathrm{~m}$ & Cultivated land/Dry land (6); Shrubland (4) & $\mathrm{S}$ \\
\hline 6 & D-S & $\begin{array}{l}\text { Yellow red soils/ red soils/ acid purple soils. Earthy yellow and brown fine-medium grain } \\
\text { loam. }\end{array}$ & $1981 \mathrm{~m}$ & Cultivated land/Dry land (7); Shrubland (4) & $\mathrm{D}$ \\
\hline 7 & $\mathrm{C}-\mathrm{S}$ & Red soils. Brown, yellow brown, brick-red and earthy yellow fine grain loam. & $2205 \mathrm{~m}$ & Cultivated land/Dry land (4); Shrubland (6) & $\mathrm{C}$ \\
\hline 8 & $\mathrm{~T}-1-\mathrm{S}$ & Red soils. Brown, brick-red and earthy yellow fine-coarse grain loam. & $2018 \mathrm{~m}$ & Cultivated land/Dry land (7); Shrubland (3) & $\mathrm{T}-1$ \\
\hline 9 & $\mathrm{~T}-2-\mathrm{S}$ & Red soils. Red and brown fine-medium grain loam. & $1835 \mathrm{~m}$ & Cultivated land/Dry land (7); Shrubland (3) & $\mathrm{T}-2$ \\
\hline 10 & $\mathrm{~J}-\mathrm{S}$ & Phaeozems/ red soils. Earthy yellow fine- medium grain loam. & $861 \mathrm{~m}$ & Cultivated land/Dry land (2); Shrubland (8) & $\mathrm{J}$ \\
\hline 11 & Ba-1-S & Red soils. Brown fine grain loam. & $1708 \mathrm{~m}$ & Cultivated land/Dry land (4); Shrubland (6) & Ba-1 \\
\hline 12 & Ba-2-S & Phaeozems/ red soils. Brown fine grain loam. The thickness of soil is extremely thin. & $958 \mathrm{~m}$ & Wasteland (4); Shrubland (6) & Ba-2 \\
\hline 13 & HTP-S & Red soils. Brown fine grain loam. & $2151 \mathrm{~m}$ & Forest land (10) & НTP \\
\hline 14 & HYA-S & Yellow brown soils. Brown fine grain loam. & $1966 \mathrm{~m}$ & Shrubland (10) & HYA \\
\hline
\end{tabular}


Table 3 Analytical methods, devices, and detection limits.

\begin{tabular}{|c|c|c|c|c|c|}
\hline Indicator & $\begin{array}{l}\text { Analytical } \\
\text { method }\end{array}$ & $\begin{array}{c}\text { Brand and the model of analysis } \\
\text { device }\end{array}$ & $\begin{array}{l}\text { Detection } \\
\text { limit }\end{array}$ & Unit & Sample \\
\hline $\mathrm{Al}_{2} \mathrm{O}_{3}$ & XRF & Shimadzu; XRF-1800X & 0.03 & wt.\% & Rock and soil \\
\hline $\mathrm{CaO}$ & $\mathrm{XRF}$ & Shimadzu; XRF-1800X & 0.02 & wt.\% & Rock and soil \\
\hline $\mathrm{TFe}_{2} \mathrm{O}_{3}$ & $\mathrm{XRF}$ & Shimadzu; XRF-1800X & 0.02 & wt.\% & Rock and soil \\
\hline $\mathrm{K}_{2} \mathrm{O}$ & $\mathrm{XRF}$ & Shimadzu; XRF-1800X & 0.03 & wt.\% & Rock and soil \\
\hline $\mathrm{Na}_{2} \mathrm{O}$ & $\mathrm{XRF}$ & Shimadzu; XRF-1800X & 0.02 & wt.\% & Rock and soil \\
\hline $\mathrm{MgO}$ & $\mathrm{XRF}$ & Shimadzu; XRF-1800X & 0.02 & wt.\% & Rock and soil \\
\hline $\mathrm{SiO}_{2}$ & $\mathrm{XRF}$ & Shimadzu; XRF-1800X & 0.05 & wt.\% & Rock and soil \\
\hline As & AFS & Jitian; AFS-820 & 0.2 & $\mu g / g$ & Rock and soil \\
\hline $\mathrm{Ba}$ & ICP-OES & ThermoFisher; ICAP6300 & 5 & $\mu \mathrm{g} / \mathrm{g}$ & Rock and soil \\
\hline $\mathrm{Cd}$ & ICP-MS & ThermoFisher; $\mathrm{X} 2$ & 0.02 & $\mu g / g$ & Rock and soil \\
\hline $\mathrm{Cr}$ & ICP-OES & ThermoFisher; ICAP6300 & 1.5 & $\mu g / g$ & Rock and soil \\
\hline Cs & ICP-MS & ThermoFisher; $\mathrm{X} 2$ & 0.2 & $\mu g / g$ & Rock and soil \\
\hline $\mathrm{Cu}$ & ICP-MS & ThermoFisher; $\mathrm{X} 2$ & 0.1 & $\mu g / g$ & Rock and soil \\
\hline $\mathrm{Hf}$ & $\mathrm{XRF}$ & Shimadzu; XRF-1800X & 0.1 & $\mu g / g$ & Rock and soil \\
\hline $\mathrm{Hg}$ & AFS & Jitian; AFS-820 & 0.0005 & $\mu \mathrm{g} / \mathrm{g}$ & Rock and soil \\
\hline $\mathrm{Nb}$ & ICP-MS & ThermoFisher; $\mathrm{X} 2$ & 1.4 & $\mu g / g$ & Rock and soil \\
\hline $\mathrm{Ni}$ & ICP-OES & ThermoFisher; ICAP6300 & 0.2 & $\mu g / g$ & Rock and soil \\
\hline $\mathrm{Pb}$ & ICP-MS & ThermoFisher; X2 & 0.2 & $\mu \mathrm{g} / \mathrm{g}$ & Rock and soil \\
\hline $\mathrm{Rb}$ & ICP-MS & ThermoFisher; $\mathrm{X} 2$ & 0.1 & $\mu g / g$ & Rock and soil \\
\hline$S$ & HFIR & Saiensi; HCS-801A & 15 & $\mu g / g$ & Rock and soil \\
\hline $\mathrm{Sr}$ & ICP-OES & ThermoFisher; ICAP6300 & 2 & $\mu \mathrm{g} / \mathrm{g}$ & Rock and soil \\
\hline Ta & ICP-MS & ThermoFisher; X2 & 0.1 & $\mu \mathrm{g} / \mathrm{g}$ & Rock and soil \\
\hline Th & ICP-MS & ThermoFisher; $\mathrm{X} 2$ & 0.2 & $\mu g / g$ & Rock and soil \\
\hline U & ICP-MS & ThermoFisher; X2 & 0.02 & $\mu \mathrm{g} / \mathrm{g}$ & Rock and soil \\
\hline $\mathrm{Zn}$ & ICP-MS & ThermoFisher; X2 & 1 & $\mu \mathrm{g} / \mathrm{g}$ & Rock and soil \\
\hline $\mathrm{Zr}$ & $\mathrm{XRF}$ & Shimadzu; XRF-1800X & 1.5 & $\mu g / g$ & Rock and soil \\
\hline C.org & VOL & - & 0.02 & $\mu g / g$ & Soil \\
\hline $\mathrm{pH}$ & ISE & Leici; PHS-3C & 0.01 & - & Soil \\
\hline Extractable As & AFS & Jitian; AFS-820 & 0.01 & $\mu g / g$ & Soil \\
\hline Extractable Cd & ICP-MS & ThermoFisher; X2 & 0.001 & $\mu g / g$ & Soil \\
\hline Extractable $\mathrm{Pb}$ & ICP-MS & ThermoFisher; X2 & 0.004 & $\mu g / g$ & Soil \\
\hline
\end{tabular}




\begin{tabular}{|c|c|c|c|c|c|c|c|c|c|c|c|c|c|c|c|}
\hline & UCC & $\epsilon-1-R$ & $\epsilon-2-R$ & $\epsilon-3-R$ & O-R & S-R & D-R & C-R & $\mathrm{T}-1-\mathrm{R}$ & T-2-R & $\mathrm{J}-\mathrm{R}$ & HTP-O & HYA-O & Ba-1-R & Ba-2-R \\
\hline & Median & Median & Median & Median & Median & Median & Median & Median & Median & Median & Median & Median & Median & Median & Median \\
\hline $\mathrm{Al}_{2} \mathrm{O}_{3}$ & 15.40 & 20.94 & 21.56 & 0.51 & 14.00 & 14.04 & 1.31 & 0.96 & 0.05 & 0.11 & 1.91 & 2.45 & 0.52 & 14.63 & 14.28 \\
\hline $\mathrm{CaO}$ & 3.59 & 0.06 & 0.06 & 54.72 & 0.05 & 0.29 & 51.68 & 46.87 & 55.34 & 30.84 & 46.14 & 12.39 & 10.78 & 7.51 & 8.43 \\
\hline $\mathrm{TFe}_{2} \mathrm{O}_{3}$ & 5.04 & 7.87 & 9.25 & 0.34 & 3.70 & 4.62 & 0.57 & 0.45 & 0.04 & 0.21 & 1.54 & 17.79 & 30.01 & 12.42 & 13.36 \\
\hline $\mathrm{K}_{2} \mathrm{O}$ & 2.80 & 5.05 & 4.12 & 0.08 & 2.32 & 3.98 & 0.34 & 0.14 & 0.01 & 0.01 & 0.29 & 0.43 & 0.17 & 0.73 & 0.53 \\
\hline $\mathrm{Na}_{2} \mathrm{O}$ & 3.27 & 0.13 & 0.15 & 0.07 & 0.16 & 0.16 & 0.09 & 0.07 & 0.08 & 0.11 & 0.11 & 0.09 & 0.11 & 2.73 & 2.62 \\
\hline $\mathrm{MgO}$ & 2.48 & 3.34 & 3.92 & 0.27 & 0.69 & 1.12 & 0.71 & 0.84 & 0.62 & 21.77 & 1.40 & 1.88 & 2.59 & 5.77 & 6.28 \\
\hline $\mathrm{SiO}_{2}$ & 66.60 & 55.44 & 53.59 & 0.68 & 71.38 & 63.84 & 3.61 & 12.23 & 0.24 & 0.26 & 7.80 & 26.93 & 29.45 & 49.77 & 46.24 \\
\hline As & 4.80 & 12.74 & 4.50 & 2.11 & 6.53 & 0.99 & 1.61 & 4.79 & 0.62 & 1.37 & 2.11 & 134.60 & 143.31 & 1.08 & 0.99 \\
\hline $\mathrm{Ba}$ & 628.00 & 608.09 & 762.87 & 44.81 & 613.67 & 595.02 & 50.20 & 46.72 & 29.35 & 30.50 & 58.63 & 137.00 & 40.51 & 246.83 & 150.08 \\
\hline $\mathrm{Cd}$ & 0.09 & 0.05 & 0.09 & 0.05 & 0.03 & 0.05 & 0.05 & 0.12 & 0.16 & 0.07 & 0.06 & 125.03 & 14.23 & 0.22 & 0.05 \\
\hline $\mathrm{Cr}$ & 92.00 & 140.05 & 150.27 & 4.93 & 75.91 & 66.43 & 7.71 & 11.56 & 5.82 & 6.11 & 10.13 & 17.51 & 9.00 & 136.06 & 298.44 \\
\hline $\mathrm{Cs}$ & 4.90 & 10.34 & 7.31 & 0.77 & 4.63 & 7.72 & 1.55 & 0.56 & 0.23 & 0.20 & 1.03 & 14.06 & 8.53 & 0.32 & 0.27 \\
\hline $\mathrm{Cu}$ & 28.00 & 43.10 & 52.98 & 2.48 & 19.60 & 24.12 & 3.01 & 3.25 & 1.49 & 2.57 & 6.90 & 5500 & 571.24 & 124.68 & 61.65 \\
\hline $\mathrm{Hf}$ & 5.30 & 2.45 & 2.60 & 0.55 & 6.60 & 5.65 & 0.90 & 1.00 & 0.65 & 0.40 & 0.70 & 4.35 & 0.85 & 3.15 & 2.95 \\
\hline $\mathrm{Hg}$ & 0.05 & 0.02 & 0.01 & 0.12 & 0.02 & 0.01 & 0.01 & 0.05 & 0.03 & 0.07 & 0.02 & 0.76 & 0.18 & 0.03 & 0.01 \\
\hline $\mathrm{Nb}$ & 12.00 & 16.15 & 15.81 & 0.59 & 13.18 & 12.43 & 2.48 & 1.70 & 0.44 & 0.28 & 1.59 & 1.46 & 0.63 & 9.97 & 8.89 \\
\hline $\mathrm{Ni}$ & 47.00 & 61.54 & 69.33 & 1.95 & 21.13 & 33.43 & 3.97 & 4.17 & 1.99 & 1.48 & 7.78 & 8.61 & 2.86 & 67.99 & 271.45 \\
\hline $\mathrm{Pb}$ & 17.00 & 10.54 & 12.20 & 7.18 & 10.00 & 9.39 & 3.39 & 3.09 & 2.41 & 4.27 & 10.96 & 54500 & 223.21 & 17.62 & 7.47 \\
\hline $\mathrm{Rb}$ & 84.00 & 237.42 & 190.80 & 11.49 & 109.62 & 173.66 & 17.22 & 10.70 & 2.04 & 2.20 & 10.15 & 26.35 & 5.94 & 16.02 & 8.28 \\
\hline $\mathrm{S}$ & 621.00 & 44.09 & 48.71 & 62.55 & 48.71 & 67.17 & 307.14 & 138.70 & 79.20 & 120.65 & 288.74 & 93500 & 13600 & 112.01 & 55.42 \\
\hline $\mathrm{Sr}$ & 320.00 & 14.93 & 34.62 & 242.35 & 25.04 & 57.26 & 275.58 & 398.03 & 72.38 & 43.89 & 246.53 & 86.44 & 34.92 & 198.48 & 193.60 \\
\hline $\mathrm{Ta}$ & 0.90 & 1.74 & 1.69 & 0.11 & 1.44 & 1.24 & 0.21 & 0.17 & 0.09 & 0.06 & 0.19 & 0.27 & 0.13 & 0.92 & 0.78 \\
\hline Th & 10.50 & 22.27 & 21.94 & 2.73 & 18.18 & 18.32 & 2.99 & 3.75 & 0.53 & 0.96 & 1.60 & 2.49 & 0.91 & 2.98 & 2.32 \\
\hline $\mathrm{U}$ & 2.70 & 2.34 & 2.75 & 0.57 & 2.73 & 2.49 & 0.60 & 0.66 & 0.86 & 0.83 & 0.84 & 0.68 & 0.49 & 0.51 & 0.44 \\
\hline $\mathrm{Zn}$ & 67.00 & 99.32 & 118.62 & 11.93 & 40.58 & 41.78 & 18.68 & 15.15 & 6.18 & 13.93 & 27.63 & 63490 & 7856.30 & 136.49 & 107.73 \\
\hline $\mathrm{Zr}$ & 193.00 & 99.05 & 98.10 & 7.95 & 216.50 & 198.60 & 20.70 & 17.20 & 5.50 & 4.20 & 17.00 & 103 & 4.90 & 110.70 & 103.65 \\
\hline
\end{tabular}


loadings for PC1-PC4 of rock/ore samples.

\begin{tabular}{|c|c|c|c|c|}
\hline & $\mathrm{PC1}$ & $\mathrm{PC} 2$ & PC3 & PC4 \\
\hline Percentage of Variance & $46.9 \%$ & $19.1 \%$ & $11.7 \%$ & $4.5 \%$ \\
\hline Cumulative Percent & $46.9 \%$ & $66.0 \%$ & $77.7 \%$ & $82.2 \%$ \\
\hline & $\mathrm{PC} 1$ & $\mathrm{PC} 2$ & $\mathrm{PC} 3$ & PC4 \\
\hline $\mathrm{Al}_{2} \mathrm{O}_{3}$ & -0.24 & -0.18 & -0.08 & 0.11 \\
\hline $\mathrm{Ca} 0$ & 0.12 & 0.37 & -0.07 & 0.17 \\
\hline $\mathrm{TFe}_{2} \mathrm{O}_{3}$ & 0.01 & -0.35 & -0.24 & -0.12 \\
\hline $\mathrm{K}_{2} \mathrm{O}$ & -0.21 & -0.23 & 0.14 & 0.02 \\
\hline $\mathrm{Na}_{2} \mathrm{O}$ & -0.12 & 0.19 & -0.37 & -0.09 \\
\hline Mg0 & -0.01 & 0.27 & -0.17 & -0.57 \\
\hline $\mathrm{SiO}_{2}$ & -0.13 & -0.30 & -0.12 & 0.25 \\
\hline As & 0.21 & -0.06 & 0.18 & -0.09 \\
\hline $\mathrm{Ba}$ & -0.21 & -0.05 & 0.18 & -0.25 \\
\hline $\mathrm{Cd}$ & 0.27 & -0.04 & 0.01 & 0.01 \\
\hline $\mathrm{Cr}$ & -0.23 & 0.01 & -0.22 & -0.20 \\
\hline Cs & 0.02 & -0.18 & 0.45 & -0.15 \\
\hline $\mathrm{Cu}$ & 0.16 & -0.28 & -0.17 & -0.10 \\
\hline $\mathrm{Hf}$ & -0.18 & 0.13 & 0.02 & 0.35 \\
\hline $\mathrm{Hg}$ & 0.21 & 0.20 & 0.15 & -0.00 \\
\hline $\mathrm{Nb}$ & -0.28 & -0.02 & -0.02 & 0.07 \\
\hline $\mathrm{Ni}$ & -0.22 & -0.03 & -0.28 & -0.15 \\
\hline $\mathrm{Pb}$ & 0.23 & -0.13 & 0.03 & 0.12 \\
\hline $\mathrm{Rb}$ & -0.21 & -0.08 & 0.35 & -0.07 \\
\hline S & 0.27 & 0.01 & 0.06 & 0.09 \\
\hline $\mathrm{Sr}$ & 0.01 & 0.37 & -0.05 & 0.30 \\
\hline $\mathrm{Ta}$ & -0.27 & 0.05 & 0.03 & -0.03 \\
\hline Th & -0.23 & 0.05 & 0.26 & -0.02 \\
\hline $\mathrm{U}$ & -0.12 & 0.25 & 0.29 & -0.20 \\
\hline $\mathrm{Zn}$ & 0.23 & -0.23 & -0.08 & -0.06 \\
\hline $\mathrm{Zr}$ & -0.24 & -0.02 & -0.01 & 0.30 \\
\hline
\end{tabular}


740 the Baoshan area.

\begin{tabular}{|c|c|c|c|c|c|c|c|c|c|c|c|c|c|c|c|c|}
\hline & Deep soil of CGB & $\mathrm{BL}$ & $\epsilon-1-S$ & $\epsilon-2-S$ & $\epsilon-3-S$ & $\mathrm{O}-\mathrm{S}$ & S-S & D-S & C-S & T-1-S & T-2-S & $\mathrm{J}-\mathrm{S}$ & HTP-S & HYA-S & Ba-1-S & Ba-2-S \\
\hline & Median & Median & Median & Median & Median & Median & Median & Median & Median & Median & Median & Median & Median & Median & Median & Median \\
\hline $\mathrm{Al}_{2} \mathrm{O}_{3}$ & 11.9 & 18.29 & 19.88 & 18.87 & 23.36 & 17.25 & 18.70 & 18.01 & 16.06 & 25.38 & 20.20 & 15.31 & 18.11 & 18.57 & 14.38 & 16.15 \\
\hline $\mathrm{CaO}$ & 2.57 & 0.62 & 0.24 & 0.16 & 0.29 & 0.09 & 0.26 & 0.50 & 0.37 & 0.62 & 3.63 & 10.02 & 2.04 & 0.59 & 4.35 & 6.30 \\
\hline $\mathrm{TFe}_{2} \mathrm{O}_{3}$ & 4.1 & 8.05 & 7.93 & 8.84 & 9.34 & 5.25 & 5.92 & 7.58 & 7.21 & 10.18 & 13.15 & 6.03 & 8.19 & 7.21 & 12.72 & 9.97 \\
\hline $\mathrm{K}_{2} \mathrm{O}$ & 2.36 & 2.56 & 2.77 & 2.06 & 2.70 & 2.78 & 3.58 & 3.38 & 0.91 & 1.36 & 1.27 & 2.31 & 1.91 & 3.13 & 0.65 & 1.44 \\
\hline $\mathrm{Na}_{2} \mathrm{O}$ & 1.81 & 0.17 & 0.15 & 0.16 & 0.13 & 0.16 & 0.11 & 0.11 & 0.10 & 0.12 & 0.10 & 0.26 & 0.25 & 0.15 & 1.36 & 0.29 \\
\hline $\mathrm{MgO}$ & 1.36 & 1.28 & 1.27 & 1.24 & 0.78 & 0.54 & 1.19 & 1.20 & 0.65 & 1.07 & 3.16 & 1.96 & 2.48 & 2.17 & 4.47 & 2.33 \\
\hline $\mathrm{SiO}_{2}$ & 67.9 & 59.68 & 50.16 & 49.06 & 49.90 & 66.27 & 61.32 & 57.79 & 61.47 & 44.74 & 39.79 & 47.80 & 45.92 & 53.28 & 44.78 & 46.40 \\
\hline As & 9 & 18.73 & 17.16 & 10.02 & 30.72 & 7.57 & 8.26 & 14.08 & 28.42 & 28.58 & 26.00 & 12.05 & 196.19 & 166.62 & 1.27 & 6.17 \\
\hline $\mathrm{Ba}$ & 522 & 341.60 & 382.65 & 435.26 & 305.27 & 538.13 & 467.65 & 319.19 & 167.63 & 257.18 & 163.96 & 248.37 & 599.92 & 855.50 & 158.38 & 258.31 \\
\hline $\mathrm{Cd}$ & 0.11 & 0.13 & 0.21 & 0.21 & 0.22 & 0.10 & 0.11 & 0.15 & 0.37 & 3.61 & 0.57 & 0.16 & 4.51 & 7.44 & 0.11 & 0.14 \\
\hline $\mathrm{Cr}$ & 50 & 119.00 & 111.93 & 115.50 & 133.40 & 94.26 & 98.89 & 119.46 & 116.75 & 164.16 & 190.05 & 92.63 & 113.42 & 112.31 & 196.85 & 184.53 \\
\hline Cs & 6 & - & 14.00 & 9.36 & 21.24 & 6.19 & 11.14 & 16.46 & 7.10 & 16.99 & 12.12 & 8.54 & 15.24 & 13.03 & 1.19 & 5.50 \\
\hline $\mathrm{Cu}$ & 19 & 45.19 & 43.86 & 41.12 & 64.07 & 28.46 & 28.84 & 30.08 & 47.96 & 63.17 & 71.86 & 30.42 & 162.39 & 623.57 & 124.71 & 49.51 \\
\hline $\mathrm{Hf}$ & 6.1 & - & 3.90 & 3.70 & 6.60 & 8.25 & 7.25 & 8.50 & 5.20 & 6.95 & 4.30 & 3.85 & 4.10 & 7.40 & 2.70 & 3.70 \\
\hline $\mathrm{Hg}$ & 0.018 & 0.11 & 0.20 & 0.23 & 0.58 & 0.05 & 0.06 & 0.06 & 0.20 & 0.27 & 0.51 & 0.03 & 0.34 & 0.40 & 0.02 & 0.02 \\
\hline $\mathrm{Nb}$ & 12 & 20.19 & 17.28 & 19.72 & 24.06 & 18.26 & 20.73 & 35.45 & 26.69 & 26.89 & 26.89 & 14.19 & 15.79 & 21.20 & 11.79 & 15.16 \\
\hline $\mathrm{Ni}$ & 22 & 57.74 & 44.95 & 32.94 & 72.19 & 28.03 & 43.35 & 50.64 & 75.53 & 110.16 & 59.59 & 48.43 & 65.99 & 64.76 & 64.53 & 132.72 \\
\hline $\mathrm{Pb}$ & 21 & 30.65 & 48.93 & 37.93 & 123.16 & 28.80 & 28.95 & 38.54 & 30.73 & 66.48 & 98.96 & 19.13 & 334.16 & 2318.46 & 8.06 & 14.98 \\
\hline $\mathrm{Rb}$ & 96 & 137.20 & 161.72 & 109.49 & 166.22 & 133.95 & 185.02 & 187.96 & 63.84 & 94.33 & 59.43 & 111.60 & 156.01 & 179.96 & 26.00 & 58.81 \\
\hline $\mathrm{S}$ & 166 & 127.01 & 469.25 & 462.79 & 199.83 & 142.21 & 152.50 & 226.58 & 190.23 & 304.23 & 181.90 & 127.43 & 764.20 & 332.54 & 98.64 & 177.28 \\
\hline $\mathrm{Sr}$ & 197 & 63.00 & 31.14 & 31.33 & 34.55 & 23.33 & 50.31 & 63.30 & 214.25 & 42.43 & 76.18 & 103.28 & 53.73 & 37.17 & 149.74 & 70.68 \\
\hline $\mathrm{Ta}$ & 1 & - & 1.19 & 1.41 & 1.65 & 1.25 & 1.51 & 2.44 & 1.95 & 2.23 & 1.99 & 1.04 & 1.17 & 1.57 & 0.75 & 1.21 \\
\hline Th & 10 & 15.69 & 20.25 & 19.84 & 26.35 & 18.36 & 20.99 & 22.14 & 17.61 & 21.73 & 12.24 & 11.30 & 17.12 & 20.20 & 3.93 & 7.54 \\
\hline $\mathrm{U}$ & 2.4 & 3.08 & 3.09 & 3.06 & 3.60 & 3.36 & 3.06 & 3.58 & 3.60 & 4.72 & 4.13 & 2.20 & 1.96 & 2.60 & 0.62 & 1.73 \\
\hline $\mathrm{Zn}$ & 60 & 100.25 & 119.19 & 84.35 & 195.10 & 43.01 & 77.17 & 100.25 & 139.94 & 219.28 & 183.51 & 68.75 & 574.92 & 3236.94 & 101.43 & 87.86 \\
\hline $\mathrm{Zr}$ & 215 & 232.15 & 134.94 & 148.20 & 246.71 & 252.80 & 246.86 & 260.37 & 179.24 & 277.65 & 204.73 & 150.18 & 148.30 & 193.35 & 117.66 & 139.49 \\
\hline C.org & 0.3 & 0.59 & 6.73 & 7.07 & 1.80 & 1.70 & 1.39 & 1.97 & 1.53 & 1.96 & 1.38 & 1.16 & 4.73 & 1.80 & 1.03 & 1.74 \\
\hline $\mathrm{pH}$ & 8.1 & 6.57 & 5.13 & 5.06 & 5.61 & 5.18 & 5.61 & 6.39 & 5.75 & 6.66 & 7.99 & 8.36 & 7.33 & 6.80 & 6.91 & 8.19 \\
\hline
\end{tabular}

\footnotetext{
Deep soil of CGB: the deep soil from China geochemical baseline project (CGB; Wang et al., 2016)
} 
BL: background level, median value of deep soil from the 1:250000 scale land quality geochemical of study area. 
Table 7 Variance explained by each principal component and component

\section{4 loadings for PC1-PC6 of soil samples.}

\begin{tabular}{|c|c|c|c|c|c|c|}
\hline & $\mathrm{PC} 1$ & $\mathrm{PC} 2$ & $\mathrm{PC} 3$ & $\mathrm{PC} 4$ & PC5 & PC6 \\
\hline Percentage of Variance & $33.3 \%$ & $27.2 \%$ & $9.0 \%$ & 8. $0 \%$ & $6.3 \%$ & 3. $9 \%$ \\
\hline Cumulative Percent & $33.3 \%$ & $60.5 \%$ & $69.5 \%$ & $77.6 \%$ & $83.9 \%$ & $87.8 \%$ \\
\hline & $\mathrm{PC1}$ & $\mathrm{PC} 2$ & $\mathrm{PC} 3$ & $\mathrm{PC} 4$ & PC5 & $\mathrm{PC6}$ \\
\hline $\mathrm{Al}_{2} \mathrm{O}_{3}$ & -0.28 & -0.08 & 0.02 & 0.03 & -0.13 & 0.21 \\
\hline $\mathrm{CaO}$ & 0.07 & -0.27 & -0.03 & 0.21 & 0.38 & -0.04 \\
\hline $\mathrm{TFe}_{2} \mathrm{O}_{3}$ & -0.14 & -0.25 & 0.06 & 0.05 & -0.30 & 0.21 \\
\hline $\mathrm{K}_{2} \mathrm{O}$ & -0.18 & 0.19 & -0.22 & -0.11 & 0.29 & 0.29 \\
\hline $\mathrm{Na}_{2} \mathrm{O}$ & -0.09 & -0.28 & -0.26 & -0.12 & -0.03 & -0.02 \\
\hline $\mathrm{Mg0}$ & 0.01 & -0.29 & -0.17 & 0.06 & 0.12 & 0.07 \\
\hline $\mathrm{SiO}_{2}$ & -0.28 & -0.04 & -0.11 & -0.15 & -0.04 & -0.16 \\
\hline As & 0.21 & 0.21 & 0.14 & 0.06 & 0.00 & -0.05 \\
\hline $\mathrm{Ba}$ & -0.09 & 0.13 & -0.41 & -0.34 & 0.00 & 0.06 \\
\hline $\mathrm{Cd}$ & 0.28 & 0.05 & 0.11 & -0.03 & -0.03 & -0.12 \\
\hline $\mathrm{Cr}$ & -0.17 & -0.25 & 0.09 & -0.01 & -0.20 & 0.29 \\
\hline Cs & -0.04 & 0.27 & 0.14 & 0.19 & 0.20 & 0.35 \\
\hline $\mathrm{Cu}$ & 0.20 & -0.13 & -0.03 & -0.35 & -0.22 & 0.06 \\
\hline $\mathrm{Hf}$ & -0.25 & 0.09 & 0.05 & -0.25 & 0.05 & -0.34 \\
\hline $\mathrm{Hg}$ & 0.14 & 0.17 & 0.27 & 0.16 & -0.26 & 0.07 \\
\hline $\mathrm{Nb}$ & -0.28 & 0.04 & 0.23 & -0.02 & -0.08 & -0.14 \\
\hline $\mathrm{Ni}$ & -0.07 & -0.26 & 0.23 & -0.02 & -0.08 & 0.34 \\
\hline $\mathrm{Pb}$ & 0.24 & 0.19 & 0.03 & -0.22 & -0.05 & 0.00 \\
\hline $\mathrm{Rb}$ & -0.14 & 0.26 & -0.16 & -0.06 & 0.26 & 0.24 \\
\hline S & 0.04 & 0.10 & -0.35 & 0.41 & -0.23 & -0.13 \\
\hline $\mathrm{Sr}$ & -0.09 & -0.25 & 0.07 & 0.10 & 0.17 & -0.41 \\
\hline $\mathrm{Ta}$ & -0.26 & 0.05 & 0.26 & 0.06 & -0.06 & -0.09 \\
\hline Th & -0.20 & 0.27 & 0.04 & 0.01 & -0.02 & 0.06 \\
\hline $\mathrm{U}$ & -0.20 & 0.20 & 0.18 & 0.15 & 0.03 & -0.11 \\
\hline $\mathrm{Zn}$ & 0.28 & 0.02 & 0.06 & -0.29 & -0.09 & -0.02 \\
\hline $\mathrm{Zr}$ & -0.28 & 0.03 & 0.12 & -0.18 & 0.01 & -0.19 \\
\hline C. org & -0.05 & 0.09 & -0.37 & 0.39 & -0.27 & -0.10 \\
\hline $\mathrm{pH}$ & 0.12 & -0.20 & 0.12 & 0.11 & 0.44 & 0.02 \\
\hline
\end{tabular}


Table 8 Level of enrichment/depletion of chemical elements from the Baoshan

746 soils from the different geological formations, relatively to the respective rocks,

747 determined by Median soil content/Median underlying rock content.

\begin{tabular}{|c|c|c|c|c|c|c|c|c|c|c|c|c|c|c|}
\hline & $\epsilon-1$ & $\epsilon-2$ & $\epsilon-3$ & $\mathrm{O}$ & $S$ & $\mathrm{D}$ & $\mathrm{C}$ & $\mathrm{T}-1$ & $\mathrm{~T}-2$ & $\mathrm{~J}$ & HTP & HYA & Ba-1 & $\mathrm{Ba}-2$ \\
\hline $\mathrm{Al}_{2} \mathrm{O}_{3}$ & 0.94 & 0.86 & 48.05 & 1.21 & 1.18 & 14.58 & 16.23 & 396.76 & 161.01 & 6.77 & 6.91 & 34.69 & 0.99 & 1.12 \\
\hline $\mathrm{CaO}$ & 6.15 & 2.58 & 0.01 & 1.64 & 0.48 & 0.01 & 0.01 & 0.01 & 0.12 & 0.32 & 0.16 & 0.05 & 0.51 & 0.87 \\
\hline $\mathrm{TFe}_{2} \mathrm{O}_{3}$ & 1.05 & 0.98 & 25.90 & 1.13 & 1.24 & 11.18 & 16.61 & 306.65 & 60.63 & 4.08 & 0.49 & 0.24 & 1.09 & 0.73 \\
\hline $\mathrm{K}_{2} \mathrm{O}$ & 0.56 & 0.57 & 29.39 & 1.09 & 0.79 & 9.80 & 15.35 & 118.93 & 102.36 & 8.95 & 4.87 & 18.25 & 0.79 & 3.05 \\
\hline $\mathrm{Na}_{2} \mathrm{O}$ & 1.09 & 1.13 & 1.93 & 0.70 & 0.79 & 1.16 & 1.34 & 1.51 & 0.85 & 2.34 & 2.23 & 1.48 & 0.54 & 0.09 \\
\hline $\mathrm{MgO}$ & 0.42 & 0.33 & 3.05 & 0.78 & 0.91 & 1.76 & 1.78 & 1.72 & 0.14 & 1.16 & 1.35 & 0.94 & 0.83 & 0.37 \\
\hline $\mathrm{SiO}_{2}$ & 0.90 & 0.95 & 72.63 & 0.91 & 0.99 & 15.31 & 4.77 & 163.20 & 133.12 & 5.35 & 1.48 & 1.83 & 0.90 & 0.93 \\
\hline As & 3.19 & 5.90 & 14.71 & 1.98 & 6.56 & 8.87 & 7.95 & 40.98 & 24.23 & 6.14 & 1.97 & 1.07 & 1.13 & 5.98 \\
\hline $\mathrm{Ba}$ & 0.61 & 0.62 & 7.35 & 1.03 & 0.86 & 6.37 & 3.06 & 9.31 & 5.61 & 3.38 & 3.73 & 20.59 & 0.89 & 1.22 \\
\hline $\mathrm{Cd}$ & 5.47 & 1.86 & 6.56 & 2.99 & 2.69 & 2.61 & 3.70 & 22.27 & 8.65 & 2.80 & 0.04 & 0.55 & 0.49 & 2.54 \\
\hline $\mathrm{Cr}$ & 0.78 & 0.80 & 25.78 & 1.19 & 1.52 & 13.00 & 11.04 & 26.27 & 28.90 & 7.28 & 6.04 & 12.95 & 1.28 & 0.62 \\
\hline $\mathrm{Cs}$ & 1.40 & 1.13 & 25.99 & 1.67 & 1.49 & 15.16 & 11.21 & 64.99 & 61.07 & 10.80 & 0.74 & 1.69 & 2.71 & 22.21 \\
\hline $\mathrm{Cu}$ & 0.98 & 0.78 & 24.59 & 1.20 & 2.07 & 10.99 & 12.09 & 39.65 & 25.79 & 3.66 & 0.05 & 1.23 & 1.13 & 0.64 \\
\hline $\mathrm{Hf}$ & 1.59 & 1.40 & 11.57 & 1.27 & 1.45 & 9.33 & 4.84 & 11.75 & 12.03 & 4.29 & 2.27 & 9.23 & 0.94 & 1.45 \\
\hline $\mathrm{Hg}$ & 14.63 & 21.24 & 4.69 & 2.01 & 3.24 & 4.15 & 3.32 & 15.23 & 4.63 & 2.16 & 0.38 & 1.98 & 0.80 & 2.59 \\
\hline $\mathrm{Nb}$ & 1.08 & 1.24 & 39.54 & 1.58 & 1.48 & 13.90 & 13.61 & 58.53 & 73.93 & 8.80 & 9.29 & 33.10 & 1.23 & 1.73 \\
\hline $\mathrm{Ni}$ & 0.80 & 0.52 & 36.15 & 1.08 & 1.01 & 11.49 & 18.86 & 61.39 & 47.20 & 5.24 & 7.15 & 22.75 & 0.96 & 0.68 \\
\hline $\mathrm{Pb}$ & 5.84 & 4.30 & 19.01 & 2.89 & 2.42 & 8.91 & 10.09 & 23.41 & 23.26 & 1.75 & 0.02 & 13.72 & 0.53 & 1.55 \\
\hline $\mathrm{Rb}$ & 0.74 & 0.60 & 13.92 & 1.20 & 0.97 & 11.39 & 5.03 & 47.64 & 32.86 & 13.74 & 5.31 & 28.58 & 1.93 & 9.13 \\
\hline $\mathrm{S}$ & 9.77 & 8.52 & 3.21 & 2.67 & 2.05 & 0.67 & 1.18 & 3.35 & 1.74 & 0.68 & 0.01 & 0.03 & 0.90 & 2.93 \\
\hline $\mathrm{Sr}$ & 2.15 & 0.77 & 0.15 & 0.88 & 0.77 & 0.29 & 0.45 & 0.62 & 1.89 & 0.42 & 0.79 & 1.05 & 0.71 & 0.39 \\
\hline $\mathrm{Ta}$ & 0.77 & 0.81 & 15.46 & 1.08 & 1.16 & 10.92 & 9.25 & 25.09 & 26.90 & 5.94 & 4.23 & 11.94 & 0.82 & 1.48 \\
\hline Th & 0.90 & 0.91 & 10.07 & 1.05 & 1.01 & 6.97 & 4.40 & 34.44 & 13.61 & 7.21 & 7.01 & 24.29 & 1.32 & 3.22 \\
\hline U & 1.44 & 1.19 & 6.96 & 1.12 & 1.28 & 6.22 & 5.38 & 6.54 & 6.18 & 2.79 & 3.23 & 5.52 & 1.45 & 3.78 \\
\hline $\mathrm{Zn}$ & 1.15 & 0.69 & 16.85 & 1.01 & 1.59 & 4.92 & 6.99 & 36.24 & 13.19 & 2.98 & 0.01 & 0.42 & 0.67 & 0.76 \\
\hline $\mathrm{Zr}$ & 1.39 & 1.42 & 29.27 & 1.19 & 1.13 & 12.44 & 10.12 & 43.31 & 46.01 & 6.37 & 1.62 & 38.14 & 1.07 & 1.49 \\
\hline
\end{tabular}

748 
Table 9 Numbers of contaminated soil samples from different geological

formations in the Baoshan area.

\begin{tabular}{|c|c|c|c|c|c|c|c|c|c|c|c|c|c|c|c|c|c|}
\hline \multirow[b]{2}{*}{ PTMs } & \multirow{2}{*}{\multicolumn{2}{|c|}{ Methods }} & \multicolumn{14}{|c|}{ Numbers of soil samples } & \multirow[b]{2}{*}{ Total } \\
\hline & & & C-1 & $\epsilon-2$ & $\epsilon-3$ & $\mathrm{O}$ & $\mathrm{S}$ & D & $\mathrm{C}-1$ & $\mathrm{~T}-1$ & $\mathrm{~T}-2$ & $\mathrm{~J}$ & HTP & HYA & Ba-1 & $\mathrm{Ba}-2$ & \\
\hline \multirow{4}{*}{ As } & \multirow{2}{*}{ Igeo } & $\mathrm{Bn}=\mathrm{BL}$ & 1 & 1 & - & - & - & - & 1 & - & - & - & 9 & 10 & - & - & 22 \\
\hline & & $\mathrm{Bn}=\mathrm{CGB}$ & 2 & 1 & 1 & - & - & - & 4 & - & 2 & - & 10 & 10 & - & - & 30 \\
\hline & & $\mathrm{EF}$ & 6 & 7 & - & 3 & 7 & 1 & - & - & - & 2 & 1 & - & 3 & 10 & 40 \\
\hline & & $>$ RSV & 4 & 3 & 6 & - & - & - & 6 & 6 & 5 & - & 10 & 10 & - & - & 50 \\
\hline \multirow{4}{*}{$\mathrm{Cd}$} & \multirow{2}{*}{ Igeo } & $\mathrm{Bn}=\mathrm{BL}$ & 2 & - & - & - & - & - & 2 & 10 & 3 & - & 9 & 10 & - & - & 36 \\
\hline & & $\mathrm{Bn}=\mathrm{CGB}$ & - & - & - & - & - & - & 5 & 10 & 4 & - & 10 & 10 & - & - & 39 \\
\hline & & $\mathrm{EF}$ & 6 & 6 & - & - & - & - & - & - & - & 1 & - & - & - & 5 & 18 \\
\hline & & $>\mathrm{RSV}$ & 3 & 1 & 3 & 1 & 1 & - & 6 & 10 & 6 & - & 10 & 10 & - & - & 51 \\
\hline \multirow{4}{*}{$\mathrm{Cr}$} & \multirow{2}{*}{ Igeo } & $\mathrm{Bn}=\mathrm{BL}$ & - & - & - & - & - & - & - & - & - & - & - & - & - & - & 0 \\
\hline & & $\mathrm{Bn}=\mathrm{CGB}$ & - & - & - & - & - & - & 1 & - & - & - & - & - & 3 & 2 & 6 \\
\hline & & $\mathrm{EF}$ & - & - & - & - & - & 1 & - & - & - & - & - & - & - & 3 & 4 \\
\hline & & $>\mathrm{RSV}$ & - & 1 & 1 & - & 1 & 1 & 1 & 4 & 3 & - & - & - & 5 & 4 & 17 \\
\hline \multirow{4}{*}{$\mathrm{Cu}$} & \multirow{2}{*}{ Igeo } & $\mathrm{Bn}=\mathrm{BL}$ & - & - & - & - & - & - & - & - & - & - & - & - & - & - & 0 \\
\hline & & $\mathrm{Bn}=\mathrm{CGB}$ & - & - & - & - & - & - & 1 & - & 2 & - & 9 & 10 & 6 & - & 28 \\
\hline & & $\mathrm{EF}$ & - & - & - & 1 & 3 & - & 2 & - & - & 1 & - & - & 1 & - & 8 \\
\hline & & $>\mathrm{RSV}$ & 3 & 3 & 7 & - & - & - & 3 & 4 & 2 & - & 9 & 10 & 8 & - & 49 \\
\hline \multirow{4}{*}{$\mathrm{Hg}$} & \multirow{2}{*}{ Igeo } & $\mathrm{Bn}=\mathrm{BL}$ & - & - & 4 & - & - & - & 1 & - & 5 & - & 2 & - & - & - & 12 \\
\hline & & $\mathrm{Bn}=\mathrm{CGB}$ & 10 & 10 & 11 & - & 2 & 1 & 7 & 10 & 8 & 1 & 10 & 10 & - & - & 79 \\
\hline & & $\mathrm{EF}$ & 10 & 10 & - & 4 & 6 & - & 1 & - & - & 3 & - & - & 2 & 5 & 41 \\
\hline & & $>\mathrm{RSV}$ & - & - & 1 & - & - & - & 1 & - & - & - & - & - & - & - & 2 \\
\hline \multirow{4}{*}{$\mathrm{Ni}$} & \multirow{2}{*}{ Igeo } & $\mathrm{Bn}=\mathrm{BL}$ & - & - & - & - & - & - & - & - & - & - & - & - & - & - & 0 \\
\hline & & $\mathrm{Bn}=\mathrm{CGB}$ & - & - & - & - & - & - & - & 1 & 2 & - & - & - & 3 & 5 & 11 \\
\hline & & $\mathrm{EF}$ & - & - & - & - & 2 & - & - & - & - & - & 2 & 1 & 1 & - & 6 \\
\hline & & $>\mathrm{RSV}$ & 3 & 1 & 6 & - & 1 & - & - & - & 3 & - & 9 & 10 & - & - & 49 \\
\hline \multirow{4}{*}{$\mathrm{Pb}$} & \multirow{2}{*}{ Igeo } & $\mathrm{Bn}=\mathrm{BL}$ & - & - & 2 & - & - & - & - & - & 2 & - & 7 & 10 & - & - & 21 \\
\hline & & $\mathrm{Bn}=\mathrm{CGB}$ & - & 1 & 4 & - & - & - & - & - & 3 & - & 9 & 10 & - & - & 27 \\
\hline & & $\mathrm{EF}$ & 10 & 10 & - & 5 & 4 & - & 2 & - & - & - & - & 1 & - & 4 & 36 \\
\hline & & $>\mathrm{RSV}$ & 1 & 2 & 9 & - & 1 & - & - & - & 3 & - & 9 & 10 & - & - & 35 \\
\hline \multirow{4}{*}{$\mathrm{Zn}$} & \multirow{2}{*}{ Igeo } & $\mathrm{Bn}=\mathrm{BL}$ & - & - & - & - & - & - & - & - & - & - & 4 & 10 & - & - & 14 \\
\hline & & $\mathrm{Bn}=\mathrm{CGB}$ & - & - & - & - & - & - & - & 1 & 2 & - & 7 & 10 & - & - & 20 \\
\hline & & $\mathrm{EF}$ & - & - & - & 1 & 2 & - & - & - & - & - & - & - & - & - & 3 \\
\hline & & $>\mathrm{RSV}$ & 1 & 3 & 1 & - & - & - & - & 7 & 3 & - & 9 & 10 & - & - & 34 \\
\hline
\end{tabular}

751 BL: background level, median value of deep soil from the 1:250000 scale land quality geochemical of study area.

752 CGB: the median value of deep soil of China geochemical Baseline project (Wang et al., 2016).

753 RSV: the risk screening values for soil contamination of agricultural land of the People's Republic of China

754 (Ministry of Ecology and Environment of The People's Republic of China, 2018).

755 Soils with the PTMs Igeo index or EF value $>2$ are thought to be contaminated in this study. 
Table 10 Average concentrations of extractable $\mathrm{As}, \mathrm{Cd}$ and $\mathrm{Pb}(\mu \mathrm{g} / \mathrm{g})$, and their percentage to total content in the soils developed on different geological formations in the Baoshan.

\begin{tabular}{lllllll}
\hline & Extractable Cd & Ex Cd Ratio & Extractable Pb & Ex Pb Ratio & Extractable As & Ex As Ratio \\
\cline { 2 - 6 } & Median & Median & Median & Median & Median & Median \\
\hline $\mathrm{G}-1$ & 0.022 & 0.116 & 0.039 & 0.001 & - & - \\
$\mathrm{G}-2$ & 0.022 & 0.127 & 0.074 & 0.002 & - & - \\
$\mathrm{\epsilon}-3$ & 0.022 & 0.097 & 0.104 & 0.001 & - & - \\
$\mathrm{O}$ & 0.019 & 0.198 & 0.049 & 0.002 & - & - \\
$\mathrm{S}$ & 0.014 & 0.161 & 0.113 & 0.004 & - & - \\
$\mathrm{D}$ & 0.016 & 0.127 & 0.137 & 0.005 & - & - \\
$\mathrm{C}$ & 0.024 & 0.087 & 0.144 & 0.022 & - & - \\
$\mathrm{T}-1$ & 0.250 & 0.068 & 3.012 & 0.043 & - & - \\
$\mathrm{T}-2$ & 0.103 & 0.158 & 6.773 & 0.071 & - & - \\
$\mathrm{J}$ & 0.015 & 0.086 & 0.879 & 0.051 & - & - \\
$\mathrm{HTP}$ & 0.794 & 0.119 & 17.511 & 0.052 & - & - \\
$\mathrm{HYA}$ & 1.657 & 0.222 & 631.620 & 0.289 & 0.001226248 & 0.00001 \\
$\mathrm{Ba}-1$ & 0.013 & 0.120 & 0.140 & 0.020 & - & - \\
$\mathrm{Ba}-2$ & 0.009 & 0.084 & 0.416 & 0.030 & - & - \\
\hline
\end{tabular}

760

Ex Cd Ratio: Extractable ratio of $\mathrm{Cd}$, calculated by $\left(\mathrm{Cd}_{\text {exteactable }}\right) /\left(\mathrm{Cd}_{\text {total content }}\right)$, same to $\mathrm{Pb}$ and $\mathrm{As}$. 


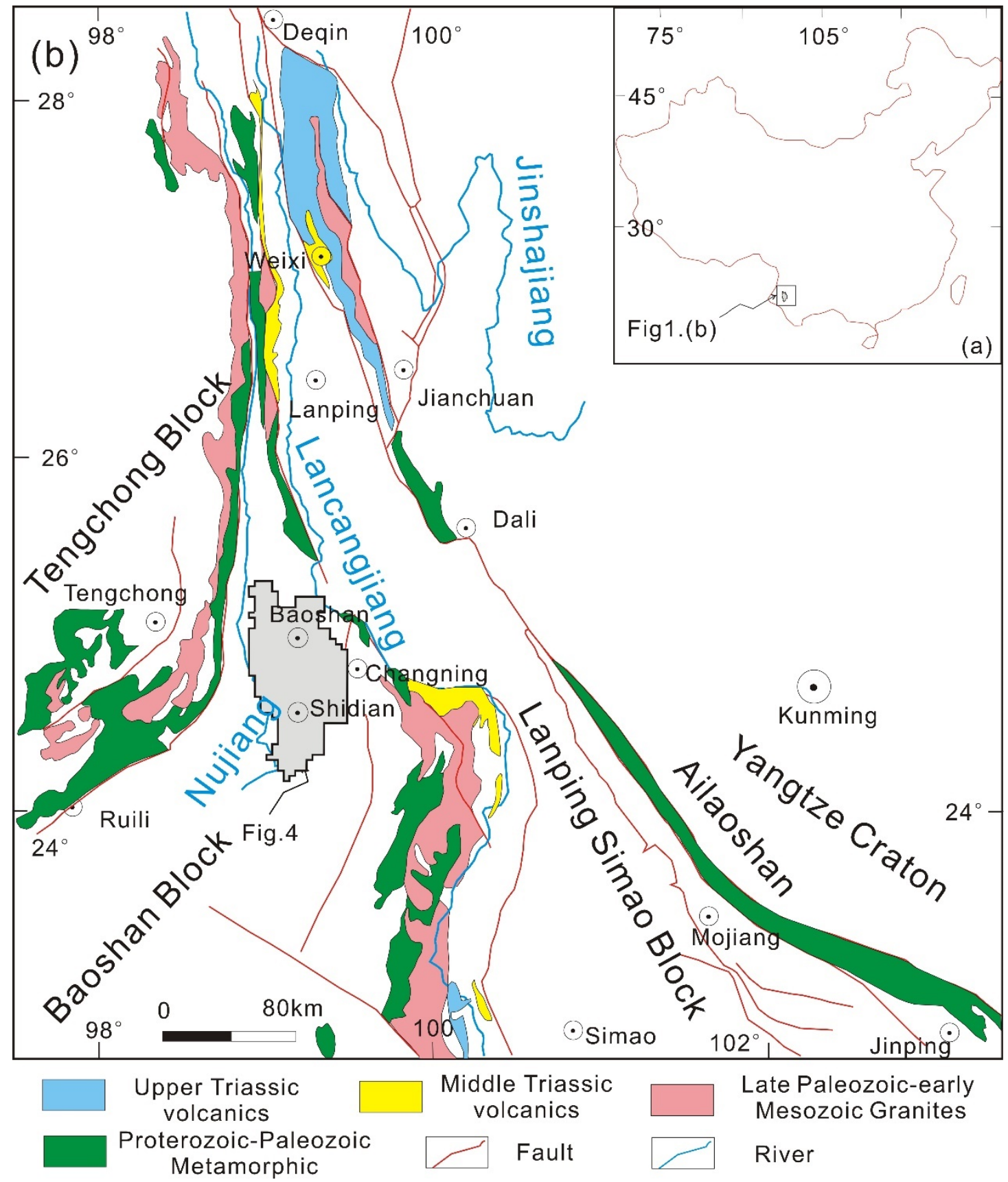



annual rainfall for study area.

(Altitude data, surface soil temperature data and rainfall data from National Earth System Science Data Sharing Infrastructure, National Science \& Technology Infrastructure of China. (http://www. geodata. cn))
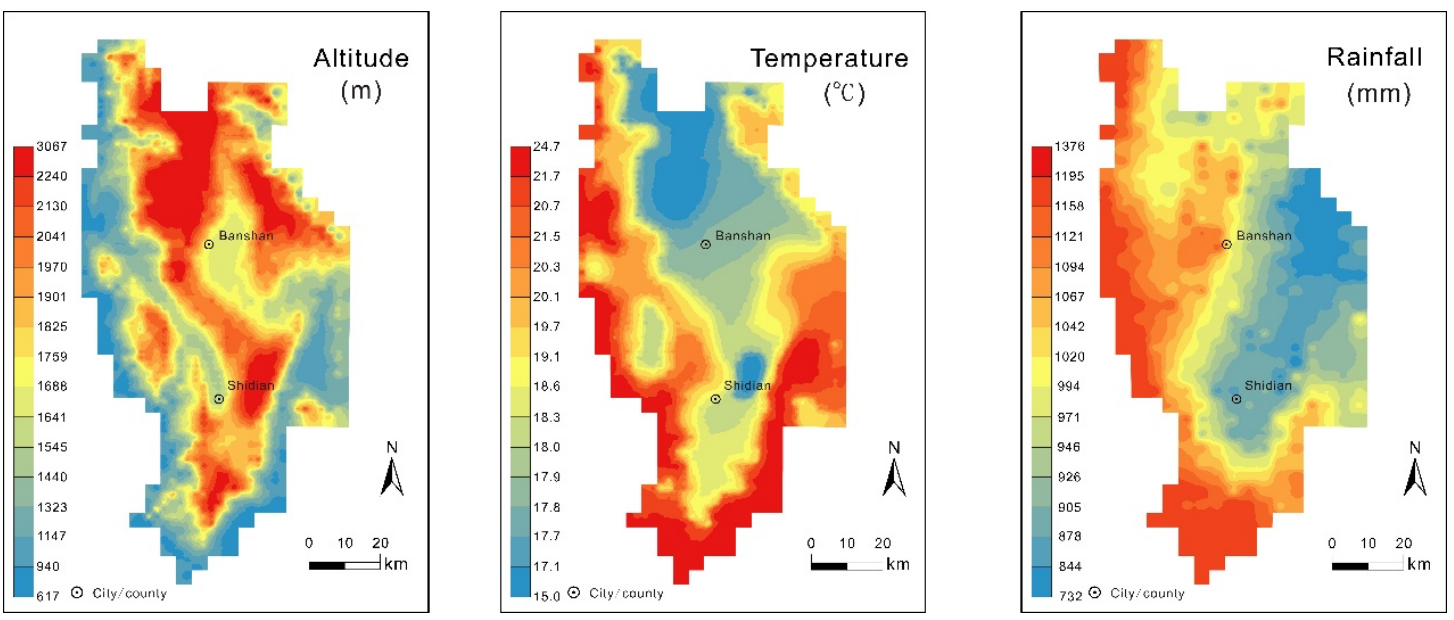


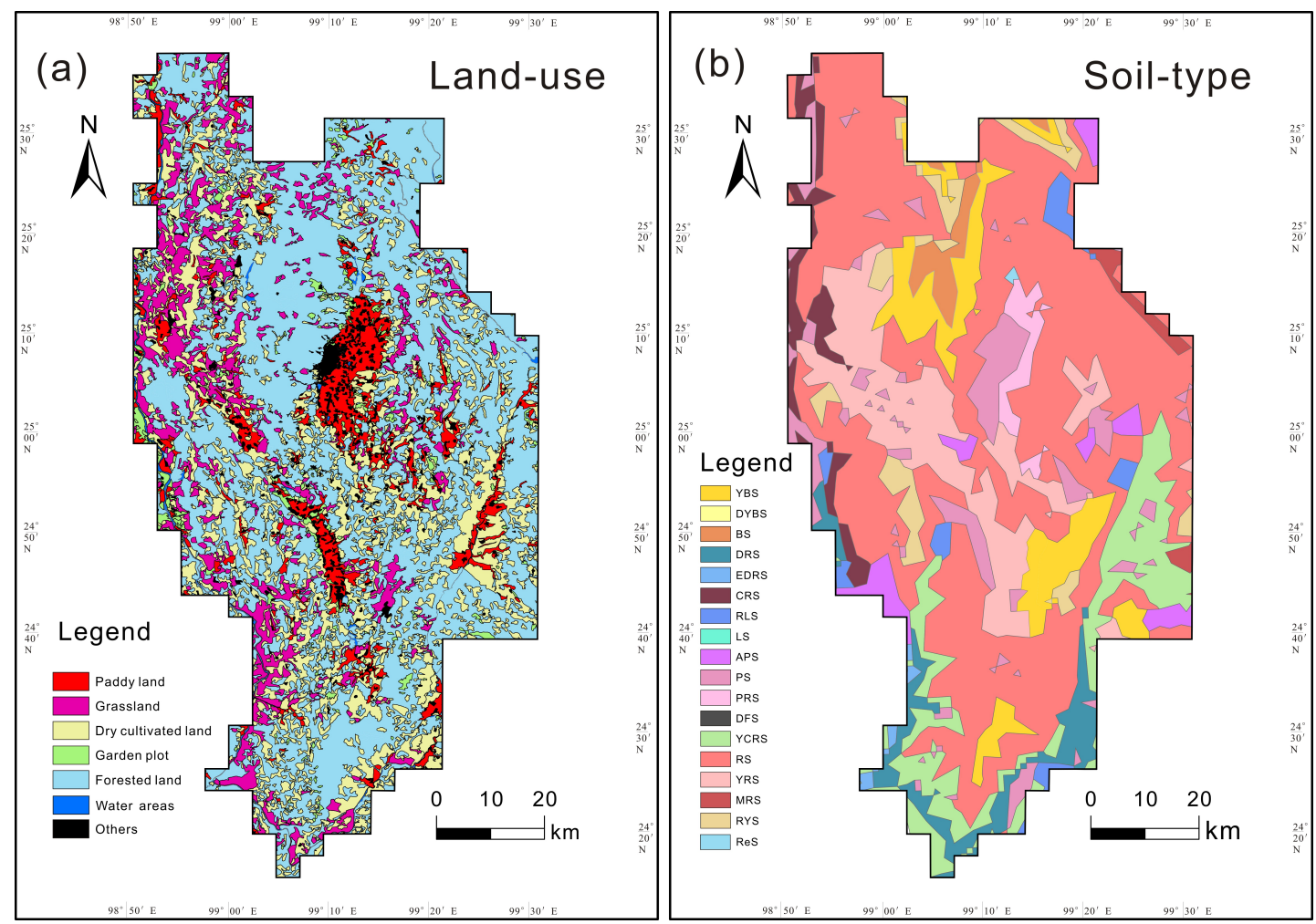

YBS: yellow brown soils; DYBS: dark yellow brown soils; BS: brown soils; DRS: dry red soils; EDRS: eluvial dry laterite; CRS: cinnamon red soils; RLS: red lime soils; LS: 1ime soils; APS: acid purple soils; PS: paddy soils; PRS; permeate rice soils; DFS: dark felty soils; YCRS: yellow crimson red soils; RS: red soils; YRS: yellow red soils; MRS: mountain red soils; RYS: rinse yellow soils; ReS: reservoir soils. 
(Geological map simplified from Yunnan geological and mineral development bureau regional geological survey team, 1981, 1983, 1986; Mineralization map from CGS mineral resources database

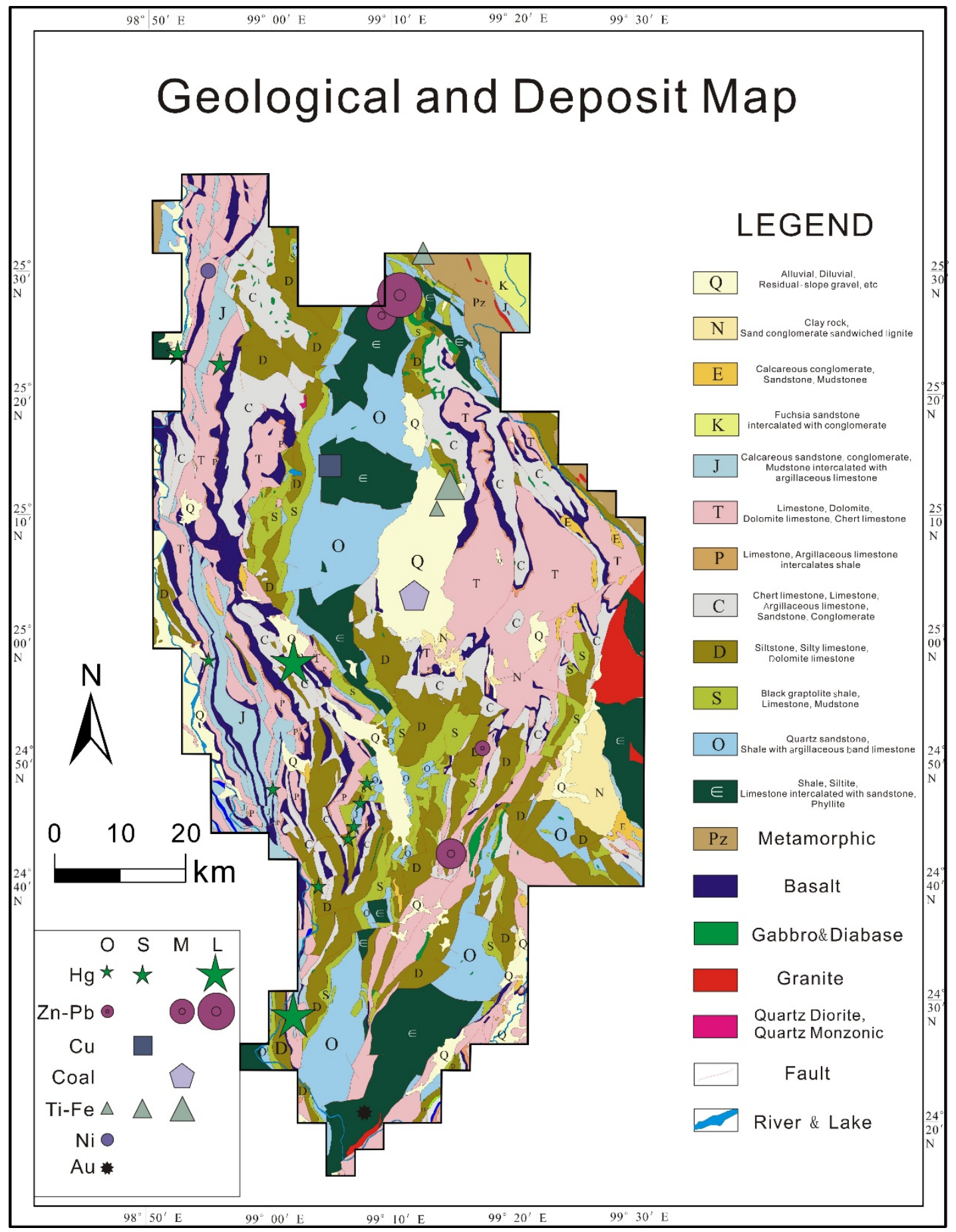

O: mineralized spot/occurrence; S small-sized deposit; M; medium-sized deposit; L: large to super large sized deposit 

mining areas in this study. Deposits also showed in this map.

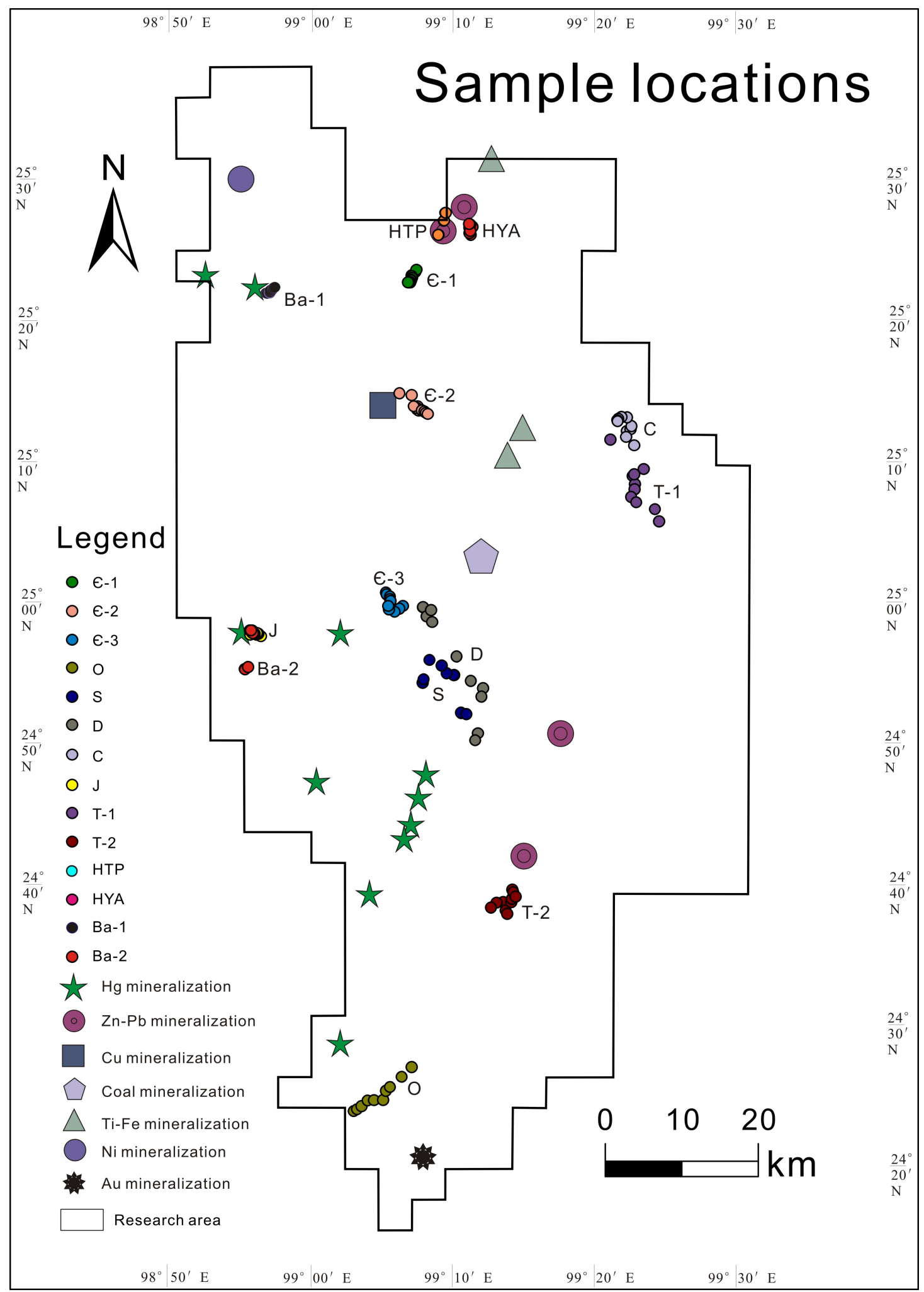


777 Fig. 6 Biplots of the principal components for the clr-transformed whole 778 composition of rock and ore samples, with parallel plots for grouping of rock/ 779 ore samples by different geological formations in the PC1-PC2 (a) and PC1-PC3

780 (b) principal component space.
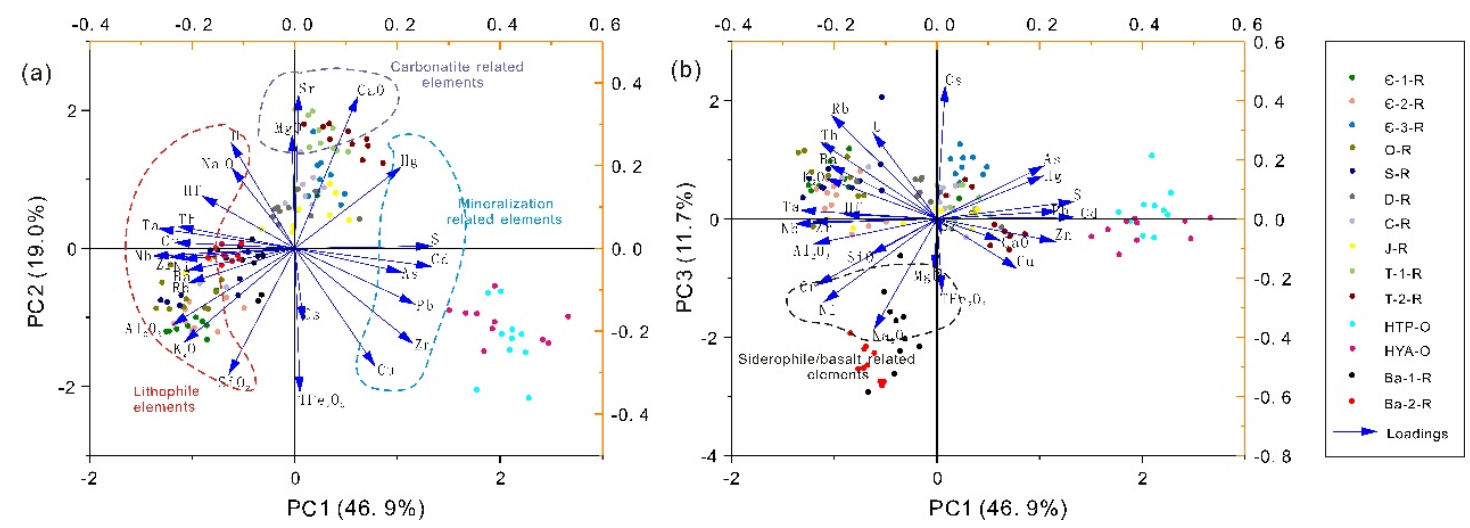
782 Fig. 7 Biplots of the principal components for the clr-transformed whole composition of soil samples, with parallel plots for grouping of soil samples by

784 overlying different geological formations in the PC1-PC2 (a) and PC2-PC3 (b)

785 principal component space.
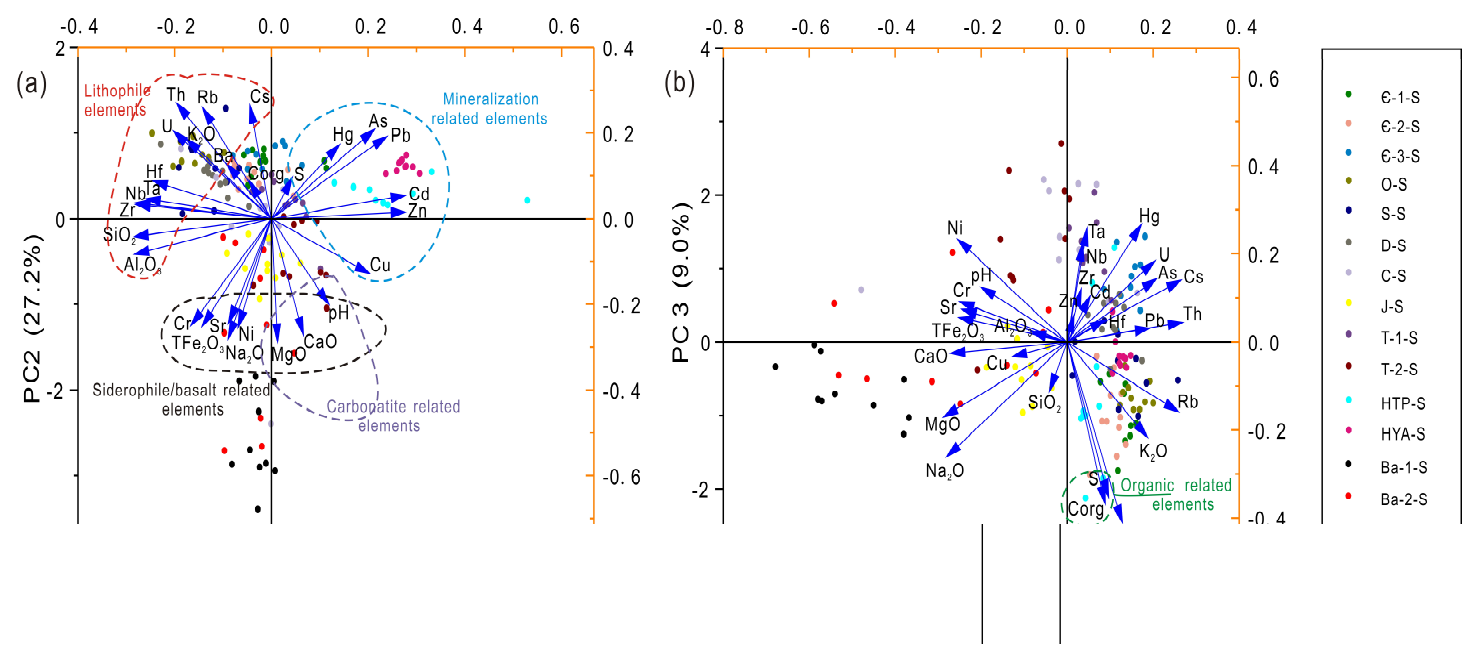
788 Fig. 8 Median values of elements ratio (soil/rock) in derived from the different

789 geological formations to reflect the PTMs enrichment and depletion in soils

790 related to their bedrocks. 

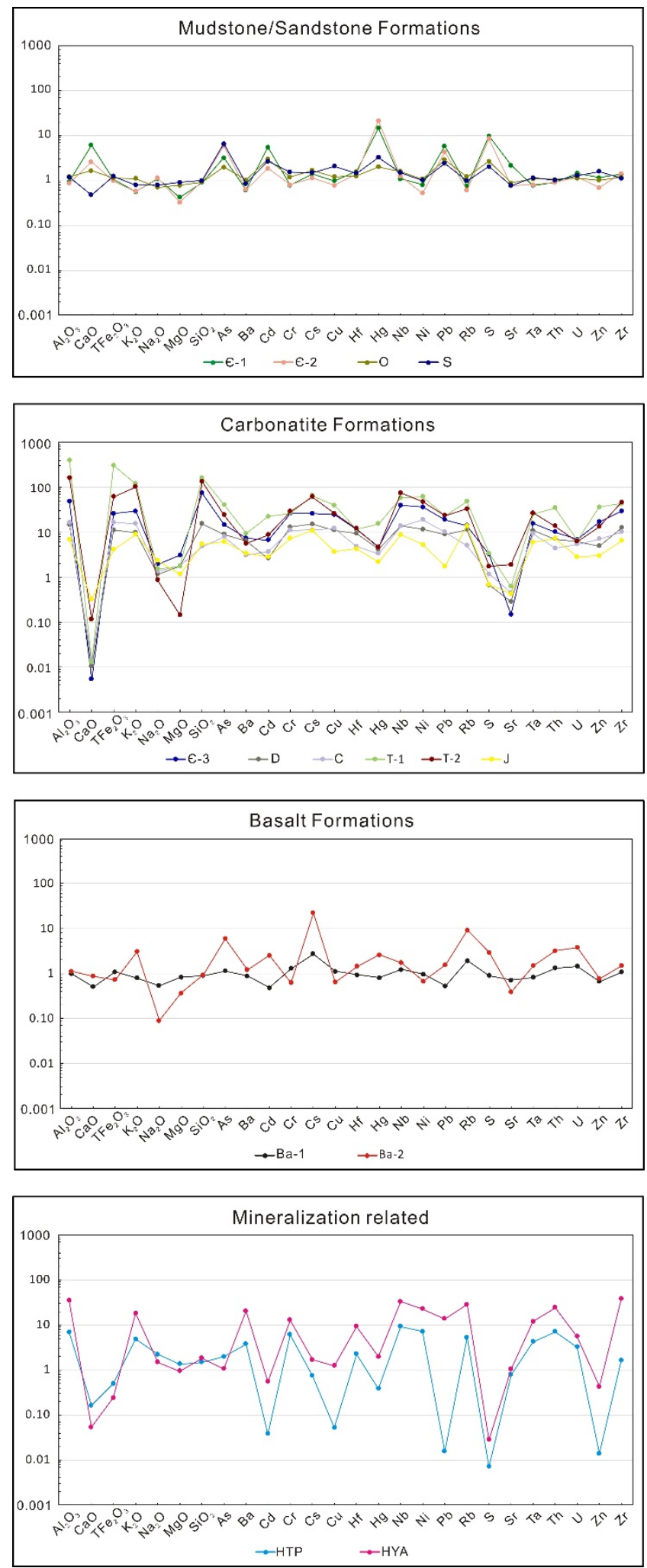